\title{
The Nucleus Accumbens: A Comprehensive Review
}

\author{
Sanjay Salgado Michael G. Kaplitt \\ Laboratory of Molecular Neurosurgery, Department of Neurological Surgery, Weill Cornell Medical College, \\ New York, N.Y., USA
}

\section{Key Words}

Nucleus accumbens · Ventral striatum · Depression .

Addiction - Obsessive-compulsive disorder · Psychosurgery livery of new agents to this region. The NAc is a fascinating and potentially rich target for stereotactic neurosurgical intervention, and analysis of existing information regarding all aspects of this structure should help potentiate therapeutic advances and reduce complications from future studies of neurosurgical intervention in this region for a variety of disorders.

(c) 2015 S. Karger AG, Basel

There is increasing interest among functional neurosurgeons in the potential for novel therapies to impact upon diseases beyond movement disorders and pain. A target of increasing interest is the nucleus accumbens (NAC), which has long been studied as a key brain region mediating a variety of behaviors, including reward and satisfaction. As such, focal modulation of the biology of the NAc with deep brain stimulation or novel biological therapies such as gene therapy or cell transplantation could have a major impact upon disorders such as depression and drug addiction. In order to both develop appropriate therapies and then deliver them in an effective fashion, a thorough understanding of the biology, physiology, and anatomy of the NAc is critical. Here, we review the existing literature regarding several areas critical to the development of new therapies, including the known pharmacology, physiology, and connectivity of the NAc, as well as evidence supporting the potential for various NAc surgical therapies in animal models. We then review the relevant anatomy of the NAc, with particular attention to the surgical anatomy, imaging, and targeting necessary to facilitate a proper localization and de-

\section{Introduction}

The nucleus accumbens (NAc) is a major component of the ventral striatum and has long been thought to be a key structure involved in mediating motivational and emotional processes, the limbic-motor interface, and the effects of certain psychoactive drugs. The NAc has been implicated in numerous neurological and psychiatric disorders, including depression, obsessive-compulsive disorder, bipolar disorder, anxiety disorders, Parkinson's disease, Alzheimer's disease, Huntington's disease, obesity, and in drug abuse and addiction. As a result, there has been a great deal of interest in stereotaxic targeting of the NAc for delivery of potentially therapeutic devices or agents. Furthermore, neurosurgical intervention into the NAc has led to encouraging outcomes in pilot studies for a range of disorders, including addiction, 
Tourette's syndrome, depression, and obsessive-compulsive disorder. Given the increasing interest in this brain region, a comprehensive understanding of the structural, biological, and clinical features of the NAc is critical. In the present report, we review the anatomical, pharmacological, and physiological attributes of the NAc, with an emphasis on those features most relevant to surgeons who may consider the NAc as a target for future therapeutic studies.

\section{History}

The first use of the term 'nucleus accumbens' is accredited to Ziehen [1] (1904) more than 100 years ago, although it has been reported $[2,3]$ that the area was first described by a number of different authors prior to this, with perhaps the earliest description emerging in 1872 . The NAc was initially an extension of the caudate nucleus, distinguishable from the rest of the striatum because of its topographic relationship with the septum, leading it to be dubbed 'nucleus accumbens septi' ('nucleus leaning against the septum') by Kappers and Theunissen [4] (1908). This terminology was rejected a few years later by Johnston [5] (1913) who, after suggesting that the structure was instead a part of the olfactory center, concluded that it should be classified as part of the septum and proposed a new name ('nucleus lateralis parolfactorius'). Johnston eventually recanted and once again called the area the 'nucleus accumbens septi', but still emphasized that this area must be recognized as an olfactory center separate from the rest of the striatum [6]. This notion originated from the hypothesis that the accumbens was predominantly related to the medial forebrain bundle (an area considered to consist largely of fibers of the olfactory system) and was furthered by Herrick [7] (1926), who dubbed the area the 'olfacto-striatum'.

However, studies from the latter half of the century found reason to challenge this terminology. While there had been evidence of olfactory input to the NAc in rodents, a dearth of afferents from the olfactory bulb or secondary olfactory regions in monkeys or cats led Heimer et al. [8] (1982) to conclude that the term 'olfactory-striatum' was misleading. Coupled with new data that found similarities between the afferent and efferent connections of the NAc and those of other striatal tissues (see Nauta et al. [9]), Heimer et al. [8] suggested that considering the NAc part of the ventral striatum was more appropriate. While the striatal nature of the NAc was still contested, evidence was accumulating to show that the NAc was similar to the striatum in terms of enzyme histochemistry [10], opiate receptors distribution [11-13], acetylcholine levels $[14,15]$, dopamine (DA) levels [16], neural connections $[9,17]$, and ontogeny $[17,18]$. While differences between the NAc and the rest of the striatum have been documented, it is now the general consensus that the accumbens is an integral, but specialized, part of the striatal complex, closely related the caudate-putamen (striatum) and separate in function and composition from the septum [19].

\section{Embryology}

During development, the prosencephalon becomes subdivided into the diencephalon and telencephalon, which continue to expand both dorsally and along the rostrocaudal axis. The basolateral aspects of the telencephalic walls eventually develop into ventricular ridges (also called ganglionic eminences). The rostral portion of these ventricular ridges $[18,20]$ - specifically, an inner layer of cells related to olfactory invagination [21] - develop into the NAc and the olfactory tubercle. $\left[{ }^{3} \mathrm{H}\right]$ Thymidine-based analysis of primate neurogenesis suggests that the accumbens develops similarly to the neostriatum. Accumbal neurons are generated over a 50-day period beginning around embryonic day 36 [22], with rodent studies noting that neurogenesis briefly continues postnatally [23-25], a notion that may apply to humans as well [21]. Interestingly, $\left[{ }^{3} \mathrm{H}\right]$ thymidine-based analysis in primates found no spatio-temporal gradients in the neuronal positioning during development [22], whereas similar analyses in rodents have had mixed findings, with studies identifying ventral-dorsal gradients [25], lateralmedial gradients [25], as well as rostrocaudal gradients [18]. This difficultly in determining a universal spatiotemporal gradient may be partially explained by the hypothesis that the accumbens arises from two distinct germinal zones along the inferior horn of the lateral ventricle, the neuroepithelium and the subependymal zone [25].

The primary neurons of the NAc are medium spiny neurons, the development of which can be influenced by environmental factors. For instance, studies have demonstrated that both prenatal and postnatal stress in animals heightens the complexity of dendritic morphology of the accumbens, altering the branching, length, and spine density of the medium spiny neurons [26-28]. Functionally, in humans, the NAc appears to have adult-like response patterns in adolescence, whereas differences can DOI: $10.1159 / 000368279$
Salgado/Kaplitt 


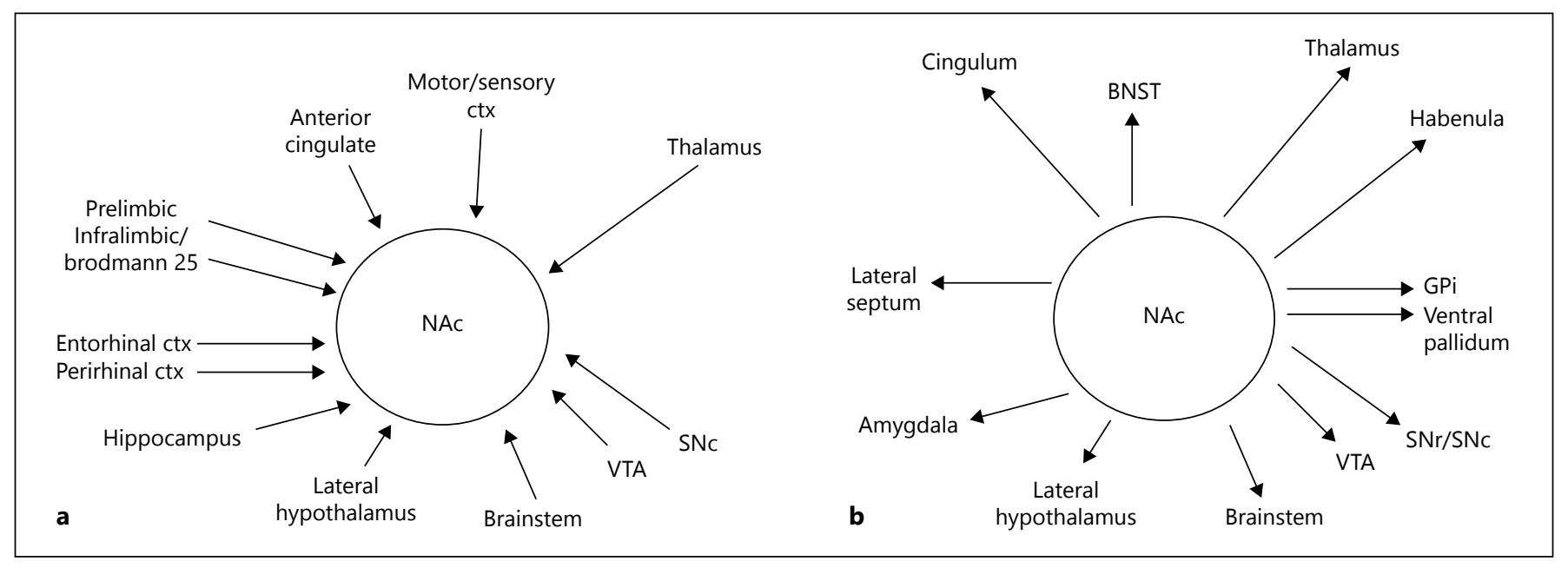

Fig. 1. Schematic representation of major afferent (a) and efferent (b) connections of the NAc. SNc = Substantia nigra pars compacta; $\mathrm{BNST}=$ bed nucleus of the stria terminalis; $\mathrm{GPi}=$ globus pallidus internus; $\mathrm{SNr}=$ substantia nigra pars reticulata; $\mathrm{ctx}=\mathrm{cortex}$.

still be observed in the prefrontal cortex and the dorsal striatum $[29,30]$. This difference in development has led to the suggestion that the activation of the subcortical system is disproportionately weighted during development, which may lead to a focus on immediate over long-term gains during adolescence [30].

\section{Anatomy}

A round, but dorsally flattened structure, the NAc is located anterior to the posterior border of the anterior commissure (AC) and lies parallel to the midline. An early 20th century anatomical study found the NAc indistinguishable from the surrounding tissue, with the only clearly defined boundary being the zona limitans, which separates the medial NAc from the septum [5]. While subsequent anatomical studies allowed for further definition, certain boundaries appeared so diffuse and transitional to merit controversy; for instance, whether the rostral pole was a distinct area [19] or an extension of the shell of the accumbens [31] (see Zahm [32], 1999). However, more modern anatomical analyses have suggested that the boundaries of the NAc are as follows: (1) posterior limit: the posterior border of the AC [33, 34]; (2) anterior limit: where the rostral limit of the internal capsule starts separating the caudate from the putamen [34]; (3) medial limit: the sagittal plane passing by the inferior border of the lateral ventricle; (4) lateral limit: a line extending downwards and laterally to the rostral edge of the internal capsule; (5) dorsal limit: the horizontal plane pass- ing under the caudate nucleus head from the inferior border of the lateral ventricle to the inferior limit of the internal capsule, and (6) ventral limit: the external capsule (lateral side) and Broca's diagonal band (medial side) anteriorly, the anterior hypothalamic nucleus posteriorly [34].

The NAc extends dorsolaterally into the putamen and dorsomedially into the caudate nucleus but lacks any sharp demarcation between the two areas [34]. Anatomical studies have suggested that the morphology of the NAc is such that the nucleus is longest on the anteriorposterior axis and shortest along the dorsal-ventral axis, suggesting that the NAc is more visible in coronal than sagittal and in sagittal than transverse magnetic resonance imaging (MRI) slices [35] (fig. 1). Previously, the NAc was thought to be less well-defined by MRI than by anatomical techniques due to a lack of a distinct signal intensity [34], but a more recent study has suggested that discerning the NAc limits with the caudate nucleus and putamen is easier by T2-weighted MRIs due to the more intense signaling that the NAc presents compared with the caudate nucleus and putamen [35].

Unique to the rest of the striatum, the accumbens can be divided into a central core surrounded medially, ventrally, and laterally by a shell [36]. This division between core and shell can only be distinguished in the caudal parts of the accumbens, which has led to the more rostral part to be referred to as the 'rostral pole' of the accumbens [37]. The differences between the shell and the core are defined by various histochemical, electrophysiological, connectional, and cellular criteria [38] but are difficult to 
discern in gross anatomical studies $[34,35]$, except perhaps at the midrostrocaudal level of the ventral striatum [39]. The AC is surrounded by the core, which in turn is surrounded, on its medial, ventral, and ventrolateral sides, by the shell [19].

Morphometric studies examining dimorphisms based on location and sex have been controversial, with studies indicating the NAc is larger on the left [40], the right [34], in males [40], and with [41] or without [35,42] sexual or hemispheric differences. The presence of an age-based dimorphism is also contested, with some studies suggesting a decrease in volume with age $[35,41,42]$, while others maintain that the NAc does not suffer any age-related atrophy [34].

\section{Organization}

While historically, there has been disagreement whether the NAc belongs to the septal system or the basal ganglia, decades of research utilizing a variety of tract-tracing, immunohistochemical, and receptor-binding methods have suggested that the accumbens is a specialized part of the striatal complex $[19,8]$, similar, but not exactly parallel, to other striatal structures such as the caudate-putamen $[37,43]$. The NAc has typically been divided by two different sets of criteria: (1) the mosaic arrangement of the patch-matrix organization as well as (2) anatomical and morphological compartmentalization of the core and shell. However, it should be noted that studies have also demonstrated additional levels of NAc organization, separate from the well-documented patch-matrix and core-shell differences. These include gradients of rostrocaudal differentiation in terms both of structure and function of the NAc [44-47] as well as organizational structures based upon differences in immunostaining and signaling molecules in the ventral and medial areas $[48,49]$.

\section{The Patch Matrix}

Similar to other striatal tissue, the NAc is characterized by a 'striosomal' or a 'patch-matrix' organization, which is a mosaic arrangement consisting of two distinct compartments [48, 50-52]. The patches are characterized by dense $\mu$-opiate receptor-binding sites [37, 53-55], while the matrix consists of weaker opiate receptor binding, high acetylcholinesterase activity, strong calcium-binding protein immunoreactivity, and a rich plexus of somatostatin fibers [37, 56-58]. This striosomal organization can also be recognized on the basis of the immunohisto- chemical distribution of several markers, including enkephalin, substance $\mathrm{P}, \mathrm{DA}$, and calcium-binding protein $[48,59,60]$.

\section{The Accumbal Core and Shell}

Unlike the rest of the striatal complex, the NAc can be divided into two distinct areas: a central core surrounded by an outer shell, each of which have unique features (some studies also consider the rostral pole, which lacks an apparent boundary separating it from the caudate-putamen and olfactory tubercle [61] and consists of uneven histochemical and immunostaining for a number of substances [37], to be a third division of the accumbens). While throughout the accumbens, the cell bodies are small to medium in size, in humans, the core region has been found to contain a low density of impregnated neurons consisting predominantly of pyramidal-like neurons with spines on secondary branches, and to a rarer extent, some multipolar neurons [62]. In contrast, the shell region has a high cell density $[62,63]$ consisting primarily of groups of well-arborized fusiform and multipolar neurons, all of which are rich in spines on secondary and tertiary dendritic branches [62]. Interestingly, morphological studies in rats have reached the seemly opposite conclusion, determining that the shell contains smaller cells with fewer dendrites and dendritic spines than those found in the core $[64,65]$.

On a molecular level, studies have noted core-shell differences in the distribution of a number of neuroactive substances and receptors, including substance $\mathrm{P}$ [39], calretinin [39], DA [66], serotonin [66], and serotonin receptors [67], with a tendency for these substances to be preferentially located in the shell than the core. Substances that are preferentially located in the core include calbin$\operatorname{din}[39,48,68]$, enkephalin $[45,47,63], \mathrm{GABA}_{\mathrm{A}}$ receptors [69], and limbic associated membrane protein [39]. Furthermore, there are core-shell differences in mRNA expression $[47,70,71]$, with differences in Fos-like immunoreactivity leading to the notion that the shell of the accumbens may be a site of antipsychotic drug action [72].

Some histological and tract tracing studies have suggested that the shell of the NAc not only harbors characteristics similar to those of striatal tissue, but also contains features analogous to the extended amygdala. These include immunohistochemical similarities, such as the presence of areas rich in neurotensin, cholecystokinin, and opioid peptides, as well as connectional similarities, including efferents to the lateral hypothalamus and afferents from the basolateral complex of the amygdala (see $[19,73,74])$. This has led to the notion that the shell area
Salgado/Kaplitt 
of the accumbens could be conceived as a transitional zone between the striatum and the extended amygdala [75]. These similarities have even raised the question of whether the NAc shell would be more appropriately classified as part of the extended amygdala, but sufficient network differences exist such that the two should most usefully be regarded as separate, interacting functional-anatomical entities [76].

\section{Afferents}

There is evidence to suggest that the NAc is the main input nucleus of the basal ganglia [77], as it receives both indirect input via the mesolimbic dopaminergic projections from the ventral tegmental area (VTA) and substantia nigra [78-80] as well as direct input in the form of glutamatergic projections from the subiculum and amygdala [80-83], hippocampus [84-88], thalamus [63, 80, 89], prelimbic [90] and prefrontal cortex [80,91-96]. Animal studies have further elucidated that the accumbens, similar to the caudate-putamen and olfactory tubercle, receives input from the allocortical and periallocortical areas as well as from the medial and lateral proisocortical areas [73, 89] (fig. 1a).

There is also evidence that the patch and matrix receive different afferents from the cortex and midbrain, with animal tracing studies determining that the patches receive innervations from the prelimbic cortex and the substantial nigra, while the matrix is innervated by the prefrontal, motor, and sensory cortical areas [57]. The prelimbic area has also been found to project mainly to the rostral half of the NAc, whereas only the lateral region of the caudal half receives frontal cortical fibers [97]. Afferents from the entorhinal and perirhinal cortices reach the NAc by way of the external capsule and terminate mainly in a ventral zone of the NAc. Those from the entorhinal area are distributed to the entire accumbens, whereas the termination field of the perirhinal afferents is largely restricted to the lateral part of the NAc [97]. Furthermore, the matrix is innervated by cortical laminae from the midline and intralaminar thalamic nuclei, which avoid the patches [11].

Additionally, there appear to be differences between the cortical origin of afferents entering the core of the NAc versus the medial shell, with the dorsal peduncular, infralimbic (the rodent equivalent of human Brodmann area 25), and posterior piriform cortices projecting to the medial shell, while the dorsal prelimbic, anterior agranular insular, anterior cingulate, and perirhinal cortices project to the core [89]. The ventral medial prefrontal cortex, in particular, sends gutamatergic projections to the shell $[98,99]$ and is thought to play a role in the reinstatement of drug-seeking behavior $[100,101]$. The afferents from the VTA also appear to extensively innervate the shell compartment of the NAc [102], whereas the substantia nigra predominantly innervates the core [103]. The caudal dorsomedial extremity of the shell (the 'septal pole' of the NAc) has been observed to be innervated by a variety of structures in the ventral forebrain, including lateral hypothalamus, deep temporal lobe, and brainstem [89]. The area between the septal pole and the most ventral 'temporal pole' contains afferents from the subiculum [97], but these terminations are inhomogeneously distributed [104]. Afferents from the dorsal agranular insular area and the intermediodorsal thalamic nucleus appear to avoid the shell of the lateral NAc, which instead receives inputs from the magnocellular basal amygdala [38].

\section{Efferents}

The main output neurons from the NAc are medium spiny neurons that project to various areas of the mesencephalon and basal ganglia. Similar to other striatal tissue, many of the efferent fibers terminate in the diencephalon or the pallidal complex, with projections reaching the stria terminalis, preoptic region, nucleus parataenialis, nucleus mediodorsalis thalami, lateral habenular nucleus, substantia nigra-ventral tegmental area, the lateral hypothalamus, cingulum, thalamus, globus pallidus, and subpallidal region $[9,17,75,105-109]$. There also appear to be projections to the amygdala $[110,111]$ and septum $[9$, 112-114], although this is not a universal finding [19] (fig. 1b).

Evidence suggests differences in efferent projections from the patches versus the matrix as well as from the core versus the shell. The patches project to the substantia nigra pars compacta, while the matrix projects to the substantia nigra pars reticulata. While both the core and shell project to the entopeduncular nucleus (the rodent equivalent of the human globus pallidus internus), only the shell appears to project diffusely throughout the rostrocaudal extent of the lateral hypothalamus and to the extended amygdala $[19,115]$. Both areas also innervate pallidal areas, but the precise locations of the projections vary depending on shell or core origin. The core projects to the dorsolateral compartment of the ventral pallidum, which lacks an appreciable amount of neurotensin, whereas the 
neurotensin-rich ventromedial ventral pallidum is innervated predominantly by the shell $[19,36,68]$.

The rostral pole of the accumbens appears to share efferents with both the core and the shell. The lateral rostral pole gives rise to core-like projections (to the rostroventral globus pallidus, subcommissural ventral pallidum, entopeduncular nucleus and an adjacent part of the lateral hypothalamus, lateral VTA, dorsal pars compacta, and structures in the lateral mesencephalic tegmentum and central grey), while the medial part of the rostral pole is more shell-like in its innervations (projecting to the subcommissural ventral pallidum, lateral preoptic region, lateral hypothalamus, VTA, dorsalmost pars compacta, retrorubral field, lateral midbrain tegmentum, and central grey) [61].

Furthermore, there appear to be differences in the efferents from the lateral and medial accumbens. The lateral accumbens has been found to project to the ventral pallidum, the subcommissural part of the globus pallidus, the entopeduncular nucleus, the substantia nigra, and the retrorubral nucleus [113]. The medial NAc has been found to project to a multitude of areas, including the ventral pallidum, the rostral part of the lateral hypothalamus, the lateral septum, the bed nucleus of the stria terminalis, the medial preoptic and hypothalamic areas, the VTA, the retrorubral nucleus, the central superior nucleus, the nucleus tegmenti pedunculopontinus, and the central gray [113]. However, other studies $[19,116]$ have been unable to replicate similar results, especially the projections to several medial hypothalamic areas, leading to the suggestion that since the medial accumbens largely contains the shell region, some of the reported connectional differences may be due to the differences between core and shell projections rather than medial-lateral differences.

\section{Circuitry}

Previous work has noted a pattern of connectivity between the patch and matrix compartments of the basal ganglia and NAc. The afferents, efferents, and dendritic processes of the neurons are compartmentally segregated and are restricted $[11,57,58,117,118]$ suggesting that the patch and matrix compose segregated, parallel systems [57]. Furthermore, it has been demonstrated that regions of the cortex that project to the NAc receive input from midline thalamic and basal amygdaloid nuclei, which also project to the same part of the NAc as their cortical target $[38,68]$.
Also of interest are the differences between the core and shell projections. The core connectivity eventually leads to premotor and supplemental motor areas of the cortex, while the shell connects to the prefrontal cortical areas as well as a range of subcortical motor areas, including the extended amygdala and lateral hypothalamus [37, $119,120]$. Further examination reveals the presence of two distinct dopaminergic circuits based on the topography of the NAc $[19,66]$. The NAc core projects to the dorsolateral ventral pallidum, which in turn projects to the subthalamic nucleus and substantia nigra, the origin of dopaminergic innervation of the striatum. On the other hand, the NAc shell projects through the ventromedial ventral pallidum to the mediodorsal nucleus, which contains a reciprocal connection with the prefrontal cortex, and the VTA, which sends dopaminergic projections to mesocortical sites $[19,61,68,121-123]$. The similarity between these projections and those of the amygdala supports the notion that the shell may represent a transitional zone between the striatum and amygdala.

These projections have been found to form networked connections within the neuronal framework, leading to the concept that the functional architecture of the basal ganglia is parallel in nature, innervating a number of structures, but following the general pattern of a corticostriato-pallido-thalamo-cortical loop [124, 125] (for example, the prefrontal cortex projects to the NAc which, in turn, innervates the ventral pallidum; the ventral pallidum, via the mediodorsal nucleus of the thalamus, then sends afferent fibers back to the prefrontal cortex, completing the circuit) via a number of re-entrant pathways $[125,126]$. There are currently five major circuits recognized, with the NAc playing a major role in the anterior cingulate circuit $[125,126]$, among other, smaller loops. The cortical circuits that link these systems may play a key role in feeding behavior [127], motivated behavior [128], and addiction [129].

\section{Function}

While immunohistochemistry and histology commanded much of the attention in the early history of the NAc research, more recent functional studies have illuminated the role of the NAc in behavior, which as a result has opened the NAc as a therapeutic target. Due to its input from the limbic system as well as output and cytochemical similarity to the motor nuclei of the basal ganglia, the accumbens has been said to be the functional interface between the limbic and motor systems $[78,130]$, 
suggesting that the accumbens is an important player in controlling the biological drives necessary for survival and reproduction. Indeed, studies have demonstrated that the NAc plays crucial roles in locomotion [131-135], learning (including both conditioned place preference $[136,137]$ and avoidance $[138,139])$, impulsivity [140], risk-taking behaviors [141], feeding behavior [127] (in animals [142-147] and humans [148]), sexual motivation (in animals [149] and humans [150]), as well as incentive and reward [151-154], especially unpredictable reward [155].

There appears to be a point of contention in the literature whether the NAc is involved in modulating goal-oriented behavior [156-159], only motivation [160,161], or part of a more complicated circuit connecting multiple independent functional systems $[162,163]$. Overall, however, the NAc appears to be a key structure in the natural reward system, which includes modulation of motivation and incentivized learning [154]. Coupled with connectional studies, these findings have led to the suggestion that the NAc plays a central role in a positive emotional response pathway, counterbalanced by a negative emotional response pathway mediated by the amygdala [164], although others believe the NAc itself may play a vital role in aversive motivation [165].

There also appears to be a division of labor between the NAc shell and core. The shell, especially the medial shell, is suspected to mediate the reinforcing properties of novelty [166], feeding behavior [167], rewarding substances [168], and drug relapse $[169,170]$. The core seems to play a crucial role in spatial learning [171], conditioned responses [172-174], responses to motivational stimuli $[166,175]$, and impulsive choices [176], likely operating in tandem with the anterior cingulate via a corticostriatal circuit [172]. Even more precise functional segregation of the accumbens can also be justified, with studies showing behavioral differences in feeding behavior after alterations in neuronal firing in the medial versus lateral shell $[177,178]$.

\section{Pharmacology}

\section{Dopamine}

The NAc first became a structure of interest among behavioral neuroscientists with the discovery that DA $[179,180]$ and DA agonist injections [181] into the NAc enhanced locomotor activity in rats, suggesting that a motor stimulant is partly mediated by D1 receptors. Further study of the accumbens has resulted in a strong body of evidence demonstrating that DA in the NAc plays a key role in the natural reward system of the brain, as well as in addiction (see below).

Dopaminergic neurons from the substantia nigra and the VTA project to the matrix, while the patches are innervated mainly by the substantia nigra [58]. Each nigral neuron appears to influence a large number of striatal neurons [182], and this signal amplification may be a key function of the nigrostriatal system in DA-based learning. The projections from the VTA, a part of the mesolimbic DA pathway, appear to extensively innervate the NAc shell [183]. Together, this has led to the hypothesis that dopaminergic innervation of the NAc core is associated with the nigrostriatal system, while that of the NAc shell is related to the mesolimbic system [66]. This is further supported by 6-OHDA lesioning, which has demonstrated that the mesostriatal DA cells innervating the patch and matrix are distinct [184].

DA turnover is higher in the accumbens than the rest of the striatum, but not significantly different between the core and shell [66]. However, there are noticeable coreshell differences in regard to DA. The shell contains a larger number of DA receptors [71], but the core has a greater DA utilization [66] and contains more DA transporters [185]. There are conflicting reports on whether the basal concentration of DA is greater in the shell [66] or core $[186,187]$, but it appears that opiate drugs increase extracellular DA in the shell more than in the core $[188,189]$. Drug-induced $5-\mathrm{HT}_{2}$ receptor occupancy favors DA release in the shell (clozapine, amperozide, risperidone, and ritanserin) [190], whereas high D2 receptor occupancy favors DA release in the core (haloperidol and raclopride) $[66,190]$. Separate from the core-shell differences, there also appears to be a rostrocaudal gradient for D1 and D2 receptors and a lateral-to-medial gradient of D2 receptors [191].

\section{GABA/Glutamate}

GABAergic neurons are a primary component of the major efferent projection from the NAc to the ventral pallidum [19, 37, 106-108] and structures such as the globus pallidus [192]. GABAergic projections originating from the NAc modulate cortical acetylcholine efflux in the basal forebrain, which has been linked to context-dependent arousal [193] and may play a role in schizophrenia [194]. Similar to DA administration, $\mathrm{GABA}_{\mathrm{A}}$ antagonists [78, 195] increase locomotion, but interestingly, GABA injection into the NAc produces both hyperactivity (after low doses) and hypoactivity (after high doses) [195, 196]. These findings may be partially explained by the notion 
that GABA antagonists facilitate DA-induced hyperactivity, while high levels of GABA depress this effect [197]. Furthermore, DA-induced hyperactivity could be blocked by preventing GABAergic stimulation of neurons in the globus pallidus [78], indicating that the DA-mediated effects on locomotion can be modulated by other neurotransmitter systems.

Locomotion behavior can also be influenced by alterations in accumbal glutamate neurons, with glutamate agonists (AMPA [198] and N-methyl-aspartate [199]) inducing hyperactivity. Administration of glutamate antagonists appears to reduce locomotion [200,201], although this hypoactivity has not been seen universally [202]. These behavioral findings may be due to an increase in DA release after exposure to glutamate agonists [203-206], a notion that is further supported by the finding that DA antagonists mitigate the stimulatory effects of glutamate agonists [207]. However, the finding that AMPA, but not amphetamine, induced hyperactivity after 6-OHDA lesions or blocked D1/D2 receptors [208] suggests a more complicated picture, in which the locomotor effects of accumbal glutamate do not solely depend on DA-mediated effects and perhaps act through other mesoaccumbal fibers. This decoupling of the dopaminergic and glutamatergic systems in the accumbens has also been suggested by animal models of cocaine relapse [209]. Animal models of addiction have also demonstrated the importance of accumbal glutamate in response reinforcement learning [210], which may play a role in nicotine reward [211], and dissociable differences in drug-seeking behavior mediated by core and shell glutamate neurons [212].

\section{Acetylcholine}

There appear to be two main cholinergic pathways that influence the reward pathways: (1) a forebrain projection from the nucleus basalis magnocellularis to the basolateral amygdala [213] that has been linked to drug relapse [214] and (2) a hindbrain projection from the mesopontine cell groups [213] (specifically the pedunculopontine tegmental nucleus (Ch5) and laterodorsal tegmental nucleus (Ch6) [215]) to the VTA and substantia nigra that modulates accumbal DA neurons $[216,217]$ and has been linked to psychosis and schizophrenia [218].

High levels of acetylcholine and choline acetyltransferase are found in the NAc, especially in the patch compartments [64] and the medial accumbens [219]. Cholinergic neurons in the striatum appear critical for long-term potentiation [220, 221] and conditioning [222]. Accumbal cholinergic activity has been linked to cessation of feeding and satiety [143-145], with more acetylcholine being re- leased after normal feeding and less release after a feedpurge regimen [143] (DA release, in contrast, seems to be independent of purging and instead based on taste). Cholinergic interneurons may be particularly important modulators of overall NAc functioning. Optogenetic inhibition of ChAT neuronal activity reduces addictive behavior in rodents [223]. Furthermore, mice lacking the gene for the small receptor-binding protein p11 exhibit depression-like behaviors, and relative inhibition of p11 using gene therapy only in NAc ChAT neurons yields similar depression-like behaviors, while a very small percentage of NAc neurons, cholinergic interneurons, clearly play a major role in NAc-regulated behaviors.

\section{Pathology}

\section{Role in Addiction}

Evidence (see above) has suggested that the NAc modulates the brain's natural reward system, likely through changes in accumbal DA. Naturally rewarding stimuli food, for instance - increase DA release in the accumbens, but importantly, the DA response wanes with repeated access $[146,147,224]$. However, it appears that the functioning of this reward system can be overwhelmed by drugs of abuse, which do not exhibit the same waning DA release with repeated exposure [225, 226]. Furthermore, studies have demonstrated that a number of substances can influence the accumbens, including cocaine [227231], opiates [232] (for review, see [233, 234]), ethanol [235], nicotine [236, 237], THC [238], heroin [238], and PCP $[239,240]$. Given the role of NAc DA in conditioned behavioral activation and discrimination of behavioral responses [241], it has been proposed that a DA transmission in the NAc regulates the effort expended to achieve a goal [242]; hence, alterations in accumbal DA may play a central role in abuse and addiction. This notion has led to the hypothesis that the mesolimbic DA system is hypofunctional in the addicted brain, resulting in a decreased interest in non-drug-related stimuli and increased sensitivity to the drug of choice [243].

The role of DA in drug use has been hypothesized for quite some time [244], and while the relationship between DA and reward has been extensively reviewed [245-249], a few points warrant highlighting. Drugs of abuse tend to increase DA in the accumbens [250] or change synaptic plasticity [251,252], whereas nonabused drugs generally do not affect accumbal DA [250] or plasticity [251,252]. After an addictive behavior is learned, groups of DA neurons in the accumbens fire to differing degrees (in pro-
Salgado/Kaplitt 
portion to the time between drug infusions [253]) and at various times [227], including before drug exposure (anticipatory response), during drug exposure, and in response to paired sensory stimuli (cue-induced drug seeking). However, human neuroimaging studies have made the link between cue-induced reinforcement and the accumbens more obscure, with some studies finding 'cues' such as paraphernalia and images leading to increased accumbal activation in heroin [254], cocaine [255, 256], and alcohol abusers [257], smokers [258], and even video game addicts [259], while others have been unable to replicate similar results (for smoking [260] and cocaine [261, 262]). However, it has been noted that this discrepancy may be due to technical difficulties isolating the NAc with current technology [260, 263].

Interestingly, addictive behavior may persist even after subsequent lesions of DA neurons [264, 265] suggesting the involvement of other neurotransmitter systems in learned behavior and reward. While a number of the other neurotransmitters, including norepinephrine [266], serotonin [267, 268], and GABA [269], are likely involved, the role of glutamate is perhaps the most well studied [251, 252, 270-276]. On a molecular level, these changes are likely mediated by a host of transcription factors, but three in particular - the cyclic-AMP response elementbinding protein (CREB) [277-281], $\triangle$ FosBand [282287], and CaMKII [288-292] - have often been implicated in addiction (for review, see [293, 294]).

\section{Role in Mood Disorders}

Patients with mood disorders have been found to have a reduced accumbal activation on functional imaging [295] and reduced volume on structural imaging [296], and a number of studies have found alterations in the VTA-NAc pathway in animal models of depression (for review, see [297]). On a molecular level, a number of factors have been linked with depression. CREB-mediated transcription in the VTA-NAc pathway may be partly responsible for changes in mood, with studies suggesting that elevations of CREB within the NAc produce anhedonia, lowered affect, and decrease the rewarding effects of drugs of abuse [298-300]. Knocking out p11, a regulator of the cell surface localization of specific serotonin receptor subtypes, has been shown to induce depressive-like behaviors [301], which are reversed by p11 gene therapy in the accumbens [302]. Together, these findings suggest an accumbal role in mood disorders and depression, a notion bolstered by the positive outcomes of treatment-resistant depression in pilot studies of accumbal deep brain stimulation (DBS) [303, 304].

Nucleus Accumbens

\section{Surgery}

\section{Surgical Anatomy}

While some studies have used the AC posterior border [305, 306], the posterior commissure (PC) [307], or the mid-commissural point $[308,309]$ as a reference point for determining DBS coordinates, the most often reported reference point is the anterior border of the $\mathrm{AC}$ at the midline [303, 304, 310-314], which has been recognized as the most reliable reference point because it is less affected by ventricular anatomy or the AC-PC distance [35] (see Mavridis and Anagnostopoulou [315]). A comprehensive anatomical examination has been done comparing both gross anatomical specimens and T2weighted MR images in order to localize the NAc within the ventral striatum [41]. Pathological analysis of $32 \mathrm{ce}-$ rebral hemispheres localized the NAc to a fairly variable area based upon hemisphere. However, in coronal sections $2 \mathrm{~mm}$ anterior to the $\mathrm{AC}$, the NAc was found 6-9 $\mathrm{mm}$ anterior to the rostral border of the AC and 1-2 mm inferior to the AC regardless of hemisphere. A similar localization of the NAc was found in sagittal sections $7 \mathrm{~mm}$ lateral to the midline, with the NAc found to be $2-4 \mathrm{~mm}$ anterior to the rostral border of the AC. Radiologic study of T2-weighted MR images found the location of the NAc to vary depending on sex, age, and hemisphere, but it was determined that in transverse sections $4 \mathrm{~mm}$ ventral to the AC-PC plane (an often reported target point for NAc DBS), the NAc was always located between 1.8 and $3.6 \mathrm{~mm}$ anterior to the $\mathrm{AC}$, regardless of age, sex, or gender. Coronal examination at sections $2 \mathrm{~mm}$ rostral to the border of the AC determined that the NAc was located $3.8-10.7 \mathrm{~mm}$ anterior to the rostral border of the AC and 0.8-3.7 $\mathrm{mm}$ inferior to the AC, while sagittal sections $8 \mathrm{~mm}$ lateral to the midline defined an area -3.8 to 7.0 anterior to the rostral border of the AC and 1.5-3.7 mm inferior to the AC, regardless of sex, age, and hemisphere examined.

Combining both MRI and gross anatomical findings, it was determined that in a coronal slice $2 \mathrm{~mm}$ anterior to the rostral border of the AC (another often cited target coordinate for NAc DBS), the area within 6-8 mm lateral to the midline and $0.8-2.0 \mathrm{~mm}$ inferior to the AC contained the NAc in every gross specimen and radiologic image analyzed. This finding, by identifying a reliable, standard localization of the NAc, presents an ideal target for the positioning of electrodes for DBS of the NAc (fig. 2). These suggested coordinates can be compared to the target coordinates used in previous NAc DBS surgeries (table 1).

Stereotact Funct Neurosurg 2015;93:75-93 DOI: $10.1159 / 000368279$ 

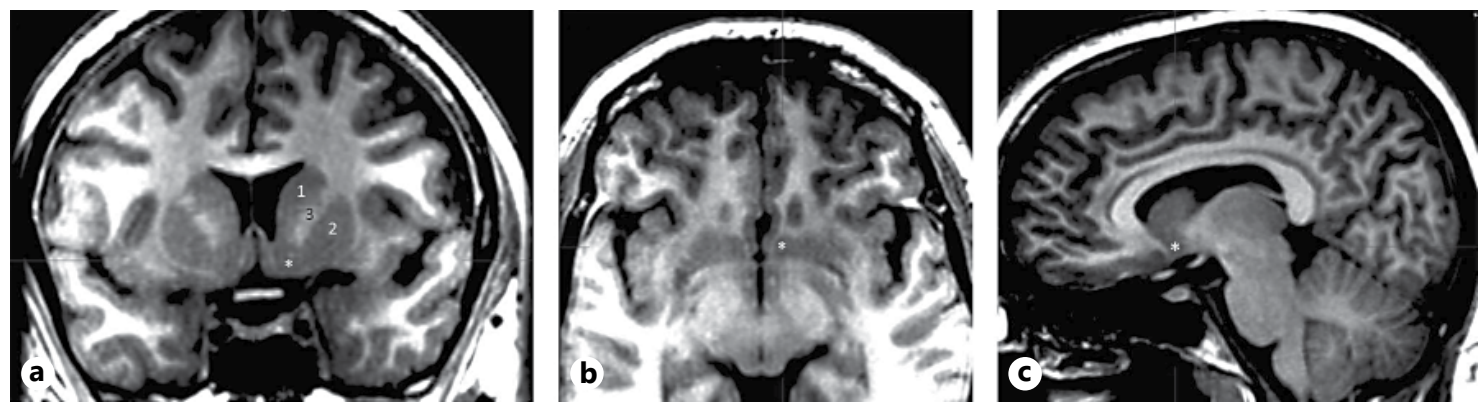

Fig. 2. Radiological localization of the NAc. Coronal (a), axial (b), and sagittal (c) representation of the NAc $\left(^{*}\right)$ on reconstructed, thin-cut spoiled gradient recalled (SPGR) sequences. 1 = Caudate; 2 = putamen; $3=$ internal capsule.

Table 1. Coordinates used for NAc DBS surgery

\begin{tabular}{|c|c|c|c|c|c|}
\hline Study & $\begin{array}{l}\text { Electrode } \\
\text { (Medtronic model No.) }\end{array}$ & $\begin{array}{l}\text { Lateral from } \\
\text { midline, } \mathrm{mm}\end{array}$ & $\begin{array}{l}\text { Rostral to anterior } \\
\mathrm{AC}, \mathrm{mm}\end{array}$ & $\begin{array}{l}\text { Inferior to } \\
\mathrm{AC}-\mathrm{PC}, \mathrm{mm}\end{array}$ & $\begin{array}{l}\text { Contact(s) activated } \\
\text { for therapy }\end{array}$ \\
\hline Mantione et al. [313] & 3389 & 7 & 3 & 4 & 2 and 3 \\
\hline Denys et al. [316] & 3389 & 7 & 3 & 4 & 2 and 3 \\
\hline Heinze et al. [326] & 3389 & $6-8$ & 2 & $3-4$ & $0,1,2$, and 3 \\
\hline Huff et al. [310] & 3387 & $6.8-7.7$ & -2.1 to 2.3 & $2.2-6.5$ & 0 and 1 \\
\hline Malone et al. [305] & 3387 & $6-7$ & $\begin{array}{l}1-2 \text { (measured from } \\
\text { postborder of the AC) }\end{array}$ & $3-4$ & 0 and/or 1 \\
\hline Kuhn et al. [311] & 3387 & 6.5 & 2.5 & 4.5 & $0,1,2$, and 3 \\
\hline Kuhn et al. [312] & 3387 & 7 & 1 & 4 & 1 and 2 \\
\hline Bewernick et al. [303] & 3387 & 7.5 & 1.5 & 4 & 0 and 1 \\
\hline Müller et al. [328] & 3387 & 6.5 & 2.7 & 4.5 & 0 and 1 \\
\hline Schlaepfer et al. [304] & 3387 & $7-8$ & 1.5 & 4 & 0 and 1 \\
\hline Voges et al. [317] & 3387 & $6-8$ & 2 & $3-4$ & 0 and 1 \\
\hline
\end{tabular}

The coordinates indicate the center of the deepest contact (contact 0 ). To date, the published studies cited above have all used Medtronic electrodes, although electrodes from other manufacturers are being tested currently. The distances between contacts in the Medtronic 3389 and 3387 electrodes are 0.5 and $1.5 \mathrm{~mm}$, respectively.

From a practical standpoint, there appears to be a discrepancy whether the target coordinates refer to the final location of the electrode tip or the center of the deepest contact. Malone et al. [305] and Denys et al. [316] placed the tip of the electrode at the target coordinate, whereas Mantione et al. [313], Bewernick et al. [303], and Voges et al. [317] placed the center of the deepest contact at the target coordinates. This inconsistency highlights the need for a uniform surgical procedure to produce comparable results. However, based on the reported targeted coordinates presented in table 1, coupled with the NAc localization work presented by Mavridis et al. [41], placing the tip of the electrode at these coordinates, rather than the center of the deepest contact, would likely result in a more accurate placement in the NAc. The trajectory in most cases passes through the anterior limb of the internal capsule, entering just anterior to the coronal suture and slightly lateral to the mid-pupillary line (fig. 3), although the exact trajectory can be influenced by the width of the lateral ventricle.

\section{Ablation Studies}

Bilateral ablation of the NAc has been attempted for the treatment of opiate $[309,318]$ and alcohol [319] addiction with evidence of efficacy, although following surgery, changes in personality characteristics, short-term memory, and attention have been noted [308]. Longterm follow-up notes continued effectiveness [318], but a lack of extensive long-term data has halted the use of ab-
Salgado/Kaplitt 


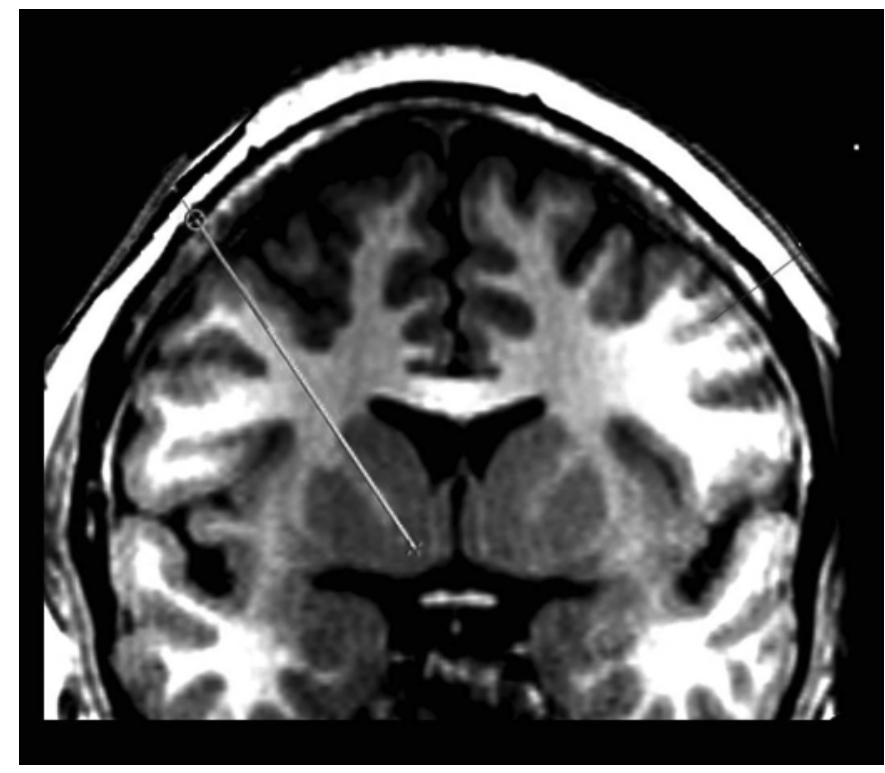

Fig. 3. Representative trajectory for stereotactic neurosurgical access to the NAc. A reconstructed coronal view through the axis of a plane that traverses a cortical gyrus, the corona radiata, and the anterior limb of the internal capsule and finally ends in the NAc.

lative treatments, especially in light of the ethical concerns of intentionally causing irreversible damage to brain structures with as many cognitive and behavioral functions as the NAc.

\section{Deep Brain Stimulation}

DBS represents an adjustable and reversible method for the modulation of neural pathway activity. The success of DBS in improving motor function in dystonia, essential tremor, and Parkinson's disease [320, 321], with better stability and fewer adverse effects compared with lesion- ing, has opened the door for trials evaluating its efficacy in treating a host of neurologic and psychiatric disorders. There have been a number of studies evaluating DBS of the NAc for the treatment of obsessive-compulsive disorder [310, 316, 322], Tourette syndrome [311, 323-325], depression [303-305], addiction to certain drugs of abuse, including alcohol [312, 326-329], heroin [330], and nicotine [313], and central pain syndrome [331, 332]. Given the known connections outlined above, it is not surprising that a recent large animal study supported the influence of NAc DBS on a variety of brain structures which could influence these and other psychiatric disorders [333]. Although the clinical studies are mostly preliminary and have used small numbers of patients, with some being observations of efficacy following DBS for a different indication, the relative safety and encouraging efficacy will likely promote more extensive clinical trials of human NAc DBS for various neuropsychiatric disorders.

\section{Summary}

The NAc is a complex and fascinating structure that has great influence over a variety of human behaviors. Clinical applications to date of focal surgical interventions into the NAc have been intriguing but likely represent only the beginning of what may become a very important area of clinical exploration for stereotactic neurosurgeons. A great deal of both animal and human data has provided a very detailed picture of the anatomy and physiology of the human NAc, but that knowledge is not exhaustive. Ongoing research into the role of this region in both normal and abnormal brain function should help facilitate further development of promising therapies targeted at this important region.

\section{References}

1 Ziehen T: Das Zentralnervensystem der Monotremen und Marsupialier. Jena, Fischer, 1904.

2 Koikegami H, Hirata Y, Oguma J: Studies on the paralimbic brain structures. Psychiatry Clin Neurosci 1967;21:151-180.

- 3 Nieto A, Mexicano G, Cappello S, Contreras $\mathrm{CM}$, Nieto D: Projections of the nucleus accumbens in the cat. Jpn J Psychiatry Neurol 1989;43:105-112.

4 Kappers CUA, Theunissen WF: Die Phylogenese des Rhinencephalons des Corpus striatum und der Vorderhirnkommissuren. Leipzig, W. Klingkardt, 1908.
5 Johnston JB: The morphology of the septum, hippocampus, and pallial commissures in reptiles and mammals. J Comp Neurol 1913; 23:371-478.

6 Johnston JB: Further contributions to the study of the evolution of the forebrain. J Comp Neurol 1923;35:337-481.

7 Herrick CJ: Brains of Rats and Men. University of Chicago Press, 1926.

$\checkmark 8$ Heimer L, Switzer RD, Van Hoesen GW: Ventral striatum and ventral pallidum: components of the motor system? Trends Neurosci 1982;5:83-87.
-9 Nauta WJ, Smith GP, Faull RL, Domesick VB: Efferent connections and nigral afferents of the nucleus accumbens septi in the rat. Neuroscience 1978;3:385-401.

10 Parent A, Olivier A: Comparative histochemical study of the corpus striatum. J Hirnforsch 1970;12:73-81.

11 Herkenham M, Pert CB: Mosaic distribution of opiate receptors, parafascicular projections and acetylcholinesterase in rat striatum. Nature 1981;291:415-418.

12 Pert CB, Kuhar MJ, Snyder SH: Opiate receptor: autoradiographic localization in rat brain. Proc Natl Acad Sci U S A 1976;73:3729-3733. 
13 Atweh SF, Kuhar MJ: Autoradiographic localization of opiate receptors in rat brain. III. The telencephalon. Brain Res 1977;134:393405.

14 Rotter A, et al: Muscarinic receptors in the central nervous system of the rat. I. Technique for autoradiographic localization of the binding of $\left[{ }^{3} \mathrm{H}\right]$ propylbenzilylcholine mustard and its distribution in the forebrain. Brain Res 1979;180:141-165.

15 Wamsley JK, Zarbin MA, Birdsall NJ, Kuhar MJ: Muscarinic cholinergic receptors: autoradiographic localization of high and low affinity agonist binding sites. Brain Res 1980;200: $1-12$.

$\checkmark 16$ Murrin LC, Gale K, Kuhar MJ: Autoradiographic localization of neuroleptic and dopamine receptors in the caudate-putamen and substantia nigra: effects of lesions. Eur J Pharmacol 1979;60:229-235.

17 Swanson LW, Cwan WM: A note on the connections and development of the nucleus accumbens. Brain Res 1975;92:324-330.

-18 Ten Donkelaar HJ, Dederen PJ: Neurogenesis in the basal forebrain of the Chinese hamster (Cricetulus griseus). I. Time of neuron origin. Anat Embryol 1979;56:331-348.

19 Heimer L, Zahm DS, Churchill L, Kalivas PW, Wohltmann C: Specificity in the projection patterns of accumbal core and shell in the rat. Neuroscience 1991;41:89-125.

20 Lammers GJ, Gribnau AA, ten Donkelaar HJ: Neurogenesis in the basal forebrain in the Chinese hamster (Cricetulus griseus). II. Site of neuron origin: morphogenesis of the ventricular ridges. Anat Embryol 1980;158:193211.

21 White LE: Development and morphology of human nucleus accumbens; in Chronister RB, De France JF (eds): The Neurobiology of the Nucleus Accumbens. Brunswick, Haer Institute, 1981, pp 198-209.

22 Brand S, Rakic P: Neurogenesis of the nucleus accumbens septi and neighboring septal nuclei in the rhesus monkey: a combined $\left[{ }^{3} \mathrm{H}\right]$ thymidine and electron microscopic study. Neuroscience 1980;5:2125-2138.

-23 Das GD, Altman J: Postnatal neurogenesis in the caudate nucleus and nucleus accumbens septi in the rat. Brain Res 1970;21:122-127.

24 Marchand R, Lajoie L: Histogenesis of the striopallidal system in the rat. Neurogenesis of its neurons. Neuroscience 1986;17:573590.

25 Bayer S: A correlated study of neurogenesis, morphogenesis and cytodifferentiation in the rat nucleus accumbens; in Chronister RB, De France JF (eds): The Neurobiology of the Nucleus Accumbens. Brunswick, Haer Institute, 1981, pp 173-197.

26 Muhammad A, Carroll C, Kolb B: Stress during development alters dendritic morphology in the nucleus accumbens and prefrontal cortex. Neuroscience 2012;216:103-109.

27 Monroy E, Hernández-Torres E, Flores G: Maternal separation disrupts dendritic morphology of neurons in prefrontal cortex, hip- pocampus, and nucleus accumbens in male rat offspring. J Chem Neuroanat 2010;40:93101.

28 McClure WO, Ishtoyan A, Lyon M: Very mild stress of pregnant rats reduces volume and cell number in nucleus accumbens of adult offspring: some parallels to schizophrenia. Dev Brain Res 2004;149:21-28.

29 Sturman DA, Moghaddam B: Striatum processes reward differently in adolescents versus adults. Proc Natl Acad Sci U S A 2012;109: 1719-1724.

30 Galvan A, et al: Earlier development of the accumbens relative to orbitofrontal cortex might underlie risk-taking behavior in adolescents. J Neurosci 2006;26:6885-6892.

31 Jongen-Rêlo AL, Voorn P, Groenewegen HJ: Immunohistochemical characterization of the shell and core territories of the nucleus accumbens in the rat. Eur J Neurosci 1994;6: 1255-1264.

32 Zahm DS: Functional-anatomical implications of the nucleus accumbens core and shell subterritories. Ann N Y Acad Sci 1999;877: 113-128.

33 Heimer L: Basal forebrain in the context of schizophrenia. Brain Res Rev 2000;31:205235.

34 Neto LL, Oliveira E, Correia F, Ferreira AG: The human nucleus accumbens: where is it? A stereotactic, anatomical and magnetic resonance imaging study. Neuromodulation 2008;11:13-22.

35 Mavridis I, Boviatsis E, Anagnostopoulou S: Anatomy of the human nucleus accumbens: a combined morphometric study. Surg Radiol Anat 2011;33:405-414.

36 Záborszky L, et al: Cholecystokinin innervation of the ventral striatum: a morphological and radioimmunological study. Neuroscience 1985; 14:427-453.

>37 Zahm DS, Brog JS: On the significance of subterritories in the 'accumbens' part of the rat ventral striatum. Neuroscience 1992;50:751767.

38 Wright CI, Groenewegen HJ: Patterns of overlap and segregation between insular cortical, intermediodorsal thalamic and basal amygdaloid afferents in the nucleus accumbens of the rat. Neuroscience 1996;73:359-373.

39 Prensa L, Richard S, Parent A: Chemical anatomy of the human ventral striatum and adjacent basal forebrain structures. J Comp Neurol 2003;460:345-367.

40 Ahsan RL, et al: Volumes, spatial extents and a probabilistic atlas of the human basal ganglia and thalamus. Neuroimage 2007;38:261270 .

41 Mavridis I, Boviatsis E, Anagnostopoulou S: Stereotactic anatomy of the human nucleus accumbens: from applied mathematics to microsurgical accuracy. Surg Radiol Anat 2011; 33:583-594.

42 Brabec J, Krásený J, Petrovický P: Volumetry of striatum and pallidum in man - anatomy, cytoarchitecture, connections, MRI and aging. Sb Lek 2003;104:13-65.
43 Herkenham M, Edley SM, Stuart J: Cell clusters in the nucleus accumbens of the rat, and the mosaic relationship of opiate receptors, acetylcholinesterase and subcortical afferent terminations. Neuroscience 1984;11:561593.

44 Zahm DS: An integrative neuroanatomical perspective on some subcortical substrates of adaptive responding with emphasis on the nucleus accumbens. Neurosci Biobehav Rev 2000;24:85-105.

45 Caboche J, Vernier P, Rogard M, Besson MJ: Haloperidol increases PPE mRNA levels in the caudal part of the nucleus accumbens in the rat. Neuroreport 1993;4:551-554.

46 Mathieu AM, Caboche J, Besson MJ: Distribution of preproenkephalin, preprotachyki$\operatorname{nin} \mathrm{A}$, and preprodynorphin mRNAs in the rat nucleus accumbens: effect of repeated administration of nicotine. Synapse 1996;23:94106.

47 Rogard M, Caboche J, Julien JF, Besson MJ: The rat nucleus accumbens: two levels of complexity in the distribution of glutamic acid decarboxylase $(67 \mathrm{kDa})$ and preproenkephalin messenger RNA. Neurosci Lett 1993;155:81-86.

48 Voorn P, Gerfen CR, Groenewegen HJ: Compartmental organization of the ventral striatum of the rat: immunohistochemical distribution of enkephalin, substance $\mathrm{P}$, dopamine, and calcium-binding protein. J Comp Neurol 1989;289:189-201.

49 Churchill L, Dilts RP, Kalivas PW: Changes in gamma-aminobutyric acid, mu-opioid and neurotensin receptors in the accumbens-pallidal projection after discrete quinolinic acid lesions in the nucleus accumbens. Brain Res 1990;511:41-54.

50 Zahm DS: The ventral striatopallidal parts of the basal ganglia in the rat - II. Compartmentation of ventral pallidal efferents. Neuroscience 1989;30:33-50.

$>51$ Olson L, Seiger Å, Fuxe K: Heterogeneity of striatal and limbic dopamine innervation: highly fluorescent islands in developing and adult rats. Brain Res 1972;44:283-288.

52 Goldman PS, Nauta WJH: An intricately patterned prefronto-caudate projection in the rhesus monkey. J Comp Neurol 1977;171: 369-385.

53 Herkenham M, Pert CB: In vitro autoradiography of opiate receptors in rat brain suggests loci of 'opiatergic' pathways. Proc Natl Acad Sci U S A 1980;77:5532-5536.

$>54$ Gerfen CR: The neostriatal mosaic: striatal patch-matrix organization is related to cortical lamination. Science 1989;246:385-388.

55 Voorn P, Brady LS, Schotte A, Berendse HW, Richfield EK: Evidence for two neurochemical divisions in the human nucleus accumbens. Eur J Neurosci 1994;6:1913-1916.

-56 Graybiel AM, Ragsdale CW Jr: Histochemically distinct compartments in the striatum of human, monkeys, and cat demonstrated by acetylthiocholinesterase staining. Proc Natl Acad Sci U S A 1978;75:5723-5726. 
57 Gerfen CR: The neostriatal mosaic: compartmentalization of corticostriatal input and striatonigral output systems. Nature 1984;311: 461-464.

58 Gerfen CR, Baimbridge KG, Miller JJ: The neostriatal mosaic: compartmental distribution of calcium-binding protein and parvalbumin in the basal ganglia of the rat and monkey. Proc Natl Acad Sci U S A 1985;82:8780-8784.

59 Graybiel AM: Correspondence between the dopamine islands and striosomes of the mammalian striatum. Neuroscience 1984;13: 1157-1187.

-60 Minamino N, Masuda H, Kangawa K, Matsuo $\mathrm{H}$ : Regional distribution of neuromedin $\mathrm{K}$ and neuromedin $\mathrm{L}$ in rat brain and spinal cord. Biochem Biophys Res Commun 1984; 124:731-738.

61 Zahm DS, Heimer L: Specificity in the efferent projections of the nucleus accumbens in the rat: comparison of the rostral pole projection patterns with those of the core and shell. J Comp Neurol 1993;327:220-232.

62 Sazdanović M, et al: Neurons of human nucleus accumbens. Vojnosanit Pregl 2011;68: 655-660.

63 Berendse HW, Groenewegen HJ: Organization of the thalamostriatal projections in the rat, with special emphasis on the ventral striatum. J Comp Neurol 1990;299:187-228.

-64 Meredith GE, Blank B, Groenewegen HJ: The distribution and compartmental organization of the cholinergic neurons in nucleus accumbens of the rat. Neuroscience 1989;31:327345.

-65 Meredith GE, Agolia R, Arts MPM, Groenewegen HJ, Zahm DS: Morphological differences between projection neurons of the core and shell in the nucleus accumbens of the rat. Neuroscience 1992;50:149-162.

66 Deutch AY, Cameron DS: Pharmacological characterization of dopamine systems in the nucleus accumbens core and shell. Neuroscience 1992;46:49-56.

67 Patel S, Roberts J, Moorman J, Reavill C: Localization of serotonin-4 receptors in the striatonigral pathway in rat brain. Neuroscience 1995;69:1159-1167.

-68 Zahm DS, Heimer L: Two transpallidal pathways originating in the rat nucleus accumbens. J Comp Neurol 1990;302:437-446.

69 Churchill L, et al: Patterns of glucose use after bicuculline-induced convulsions in relationship to gamma-aminobutyric acid and muopioid receptors in the ventral pallidum functional markers for the ventral pallidum. Brain Res 1992;581:39-45.

-70 Koylu EO, Couceyro PR, Lambert PD, Kuhar MJ: Cocaine- and amphetamine-regulated transcript peptide immunohistochemical localization in the rat brain. J Comp Neurol 1998;391:115-132.

$\checkmark 71$ Le Moine C, Bloch B: Expression of the D3 dopamine receptor in peptidergic neurons of the nucleus accumbens: comparison with the D1 and D2 dopamine receptors. Neuroscience 1996;73:131-143.
2 Deutch AY, Lee MC, Iadarola MJ: Regionally specific effects of atypical antipsychotic drugs on striatal Fos expression: the nucleus accumbens shell as a locus of antipsychotic action. Mol Cell Neurosci 1992;3:332-341.

73 Heimer L, et al: The accumbens: beyond the core-shell dichotomy. J Neuropsychiatry Clin Neurosci 1997;9:354-381.

74 Alheid GF, Heimer L: New perspectives in basal forebrain organization of special relevance for neuropsychiatric disorders: the striatopallidal, amygdaloid, and corticopetal components of substantia innominata. Neuroscience 1988;27:1-39.

75 Heimer L, Alheid GF: Piecing together the puzzle of basal forebrain anatomy. Adv Exp Med Biol 1991;295:1-42.

76 Zahm DS: Is the caudomedial shell of the nucleus accumbens part of the extended amygdala? A consideration of connections. Crit Rev Neurobiol 1998;12:245-265.

77 Nicola SM: The nucleus accumbens as part of a basal ganglia action selection circuit. Psychopharmacology (Berl) 2007;191:521-550.

78 Mogenson GJ, Jones DL, Yim CY: From motivation to action: functional interface between the limbic system and the motor system. Prog Neurobiol 1980;14:69-97.

79 Fallon JH, Moore RY: Catecholamine innervation of the basal forebrain. IV. Topography of the dopamine projection to the basal forebrain and neostriatum. J Comp Neurol 1978; 180:545-580.

80 Phillipson OT, Griffiths AC: The topographic order of inputs to nucleus accumbens in the rat. Neuroscience 1985;16:275-296.

81 Fuller TA, Russchen FT, Price JL: Sources of presumptive glutamergic/aspartergic afferents to the rat ventral striatopallidal region. J Comp Neurol 1987;258:317-338.

82 Mcdonald AJ: Organization of amygdaloid projections to the prefrontal cortex and associated striatum in the rat. Neuroscience 1991; 44:1-14.

83 Groenewegen HJ, Becker NE, Lohman AH: Subcortical afferents of the nucleus accumbens septi in the cat, studied with retrograde axonal transport of horseradish peroxidase and bisbenzimid. Neuroscience 1980;5:1903-1916.

84 DeFrance JF, Marchand JF, Sikes RW, Chronister RB, Hubbard JI: Characterization of fimbria input to nucleus accumbens. J Neurophysiol 1985;54:1553-1567.

85 Yang CR, Mogenson GJ: Electrophysiological responses of neurones in the nucleus accumbens to hippocampal stimulation and the attenuation of the excitatory responses by the mesolimbic dopaminergic system. Brain Res 1984;324;69-84.

86 Zaczek R, Hedreen JC, Coyle JT: Evidence for a hippocampal-septal glutamatergic pathway in the rat. Exp Neurol 1979;65:145-156.

87 Lopes da Silva FH, Arnolds DE, Neijt HC: A functional link between the limbic cortex and ventral striatum: physiology of the subiculum accumbens pathway. Exp Brain Res 1984;55: 205-214.
88 Kelley AE, Domesick VB: The distribution of the projection from the hippocampal formation to the nucleus accumbens in the rat: an anterograde and retrograde-horseradish peroxidase study. Neuroscience 1982;7:2321-2335.

-89 Brog JS, Salyapongse A, Deutch AY, Zahm DS: The patterns of afferent innervation of the core and shell in the 'accumbens' part of the rat ventral striatum: immunohistochemical detection of retrogradely transported fluoro-gold. J Comp Neurol 1993;338:255278.

90 Beckstead RM: An autoradiographic examination of corticocortical and subcortical projections of the mediodorsal-projection (prefrontal) cortex in the rat. J Comp Neurol 1979;184:43-62.

91 Buchanan SL, Thompson RH, Maxwell BL, Powell DA: Efferent connections of the medial prefrontal cortex in the rabbit. Exp Brain Res 1994;100:469-483.

92 Chiba T, Kayahara T, Nakano K: Efferent projections of infralimbic and prelimbic areas of the medial prefrontal cortex in the Japanese monkey, Macaca fuscata. Brain Res 2001;888:83-101.

93 Ferry AT, Ongür D, An X, Price JL: Prefrontal cortical projections to the striatum in macaque monkeys: evidence for an organization related to prefrontal networks. J Comp Neurol 2000;425:447-470.

$\$ 94$ Gorelova N, Yang CR: The course of neural projection from the prefrontal cortex to the nucleus accumbens in the rat. Neuroscience 1997;76:689-706.

-95 Montaron MF, Deniau JM, Menetrey A, Glowinski J, Thierry AM: Prefrontal cortex inputs of the nucleus accumbens-nigro-thalamic circuit. Neuroscience 1996;71:371382.

96 Morino P, Mascagni F, McDonald A, Hökfelt T: Cholecystokinin corticostriatal pathway in the rat: evidence for bilateral origin from medial prefrontal cortical areas. Neuroscience 1994;59:939-952.

97 Groenewegen HJ, Room P, Witter MP, Lohman AH: Cortical afferents of the nucleus accumbens in the cat, studied with anterograde and retrograde transport techniques. Neuroscience 1982;7:977-996.

$\$ 98$ Sesack SR, Deutch AY, Roth RH, Bunney BS: Topographical organization of the ef ferent projections of the medial prefrontal cortex in the rat: an anterograde tract-tracing study with Phaseolus vulgaris leucoagglutinin. J Comp Neurol 1989;290:213242 .

99 Groenewegen HJ, Wright CI, Beijer AV, Voorn P: Convergence and segregation of ventral striatal inputs and outputs. Ann N Y Acad Sci 1999;877:49-63.

100 Bossert JM, et al: Role of projections from ventral medial prefrontal cortex to nucleus accumbens shell in context-induced reinstatement of heroin seeking. J Neurosci 2012;32:4982-4991. 
101 Bossert JM, et al: Ventral medial prefrontal cortex neuronal ensembles mediate contextinduced relapse to heroin. Nature Neurosci 2011;14:420-422.

102 Gerfen CR, Herkenham M, Thibault J: The neostriatal mosaic: II. Patch- and matrix-directed mesostriatal dopaminergic and nondopaminergic systems. J Neurosci 1987;7: 3915-3934.

103 Nirenberg MJ, Vaughan RA, Uhl GR, Kuhar MJ, Pickel VM: The dopamine transporter is localized to dendritic and axonal plasma membranes of nigrostriatal dopaminergic neurons. J Neurosci 1996;16:436-447.

-104 Groenewegen HJ, Vermeulen-Van der Zee E, te Kortschot A, Witter MP: Organization of the projections from the subiculum to the ventral striatum in the rat. A study using anterograde transport of Phaseolus vulgaris leucoagglutinin. Neuroscience 1987; 23:103-120.

105 Williams DJ, Crossman AR, Slater P: The efferent projections of the nucleus accumbens in the rat. Brain Res 1977;130:217-227.

106 Churchill L, Kalivas PW: A topographically organized gamma-aminobutyric acid projection from the ventral pallidum to the nucleus accumbens in the rat. J Comp Neurol 1994;345:579-595.

107 Yang CR, Mogenson GJ: Ventral pallidal neuronal responses to dopamine receptor stimulation in the nucleus accumbens. Brain Res 1989;489:237-246.

108 Záborszky L, Cullinan WE: Projections from the nucleus accumbens to cholinergic neurons of the ventral pallidum: a correlated light and electron microscopic double-immunolabeling study in rat. Brain Res 1992; 570:92-101.

109 Mogenson GJ, Swanson LW, Wu M: Neural projections from nucleus accumbens to globus pallidus, substantia innominata, and lateral preoptic-lateral hypothalamic area: an anatomical and electrophysiological investigation in the rat. J Neurosci 1983;3:189-202.

$\$ 110$ Russchen FT, Bakst I, Amaral DG, Price JL: The amygdalostriatal projections in the monkey. An anterograde tracing study. Brain Res 1985;329:241-257.

111 Ito N, Ishida H, Miyakawa F, Naito H: Microelectrode study of projections from the amygdaloid complex to the nucleus accumbens in the cat. Brain Res 1974;67:338-341.

$\$ 112$ Conrad LC, Pfaff DW: Autoradiographic tracing of nucleus accumbens efferents in the rat. Brain Res 1976;113:589-596.

113 Groenewegen HJ, Russchen FT: Organization of the efferent projections of the nucleus accumbens to pallidal, hypothalamic, and mesencephalic structures: a tracing and immunohistochemical study in the cat. J Comp Neurol 1984;223:347-367.

114 Powell EW, Leman RB: Connections of the nucleus accumbens. Brain Res 1976;105: 389-403.

115 van Kuyck K, et al: Behavioural and physiological effects of electrical stimulation in the nucleus accumbens: a review. Acta Neurochir Suppl 2007;97:375-391.

116 Troiano R, Siegel A: Efferent connections of the basal forebrain in the cat: the nucleus accumbens. Exp Neurol 1978;61:185-197.

117 Goldman-Rakic PS: Cytoarchitectonic heterogeneity of the primate neostriatum: subdivision into island and matrix cellular compartments. J Comp Neurol 1982;205:398413.

118 Donoghue JP, Herkenham M: Neostriatal projections from individual cortical fields conform to histochemically distinct striatal compartments in the rat. Brain Res 1986; 365:397-403.

119 Alexander GE, Crutcher MD, DeLong MR: Basal ganglia-thalamocortical circuits: parallel substrates for motor, oculomotor, 'prefrontal' and 'limbic' functions. Prog Brain Res 1990;85:119-146.

120 Alexander GE, DeLong MR, Strick PL: Parallel organization of functionally segregated circuits linking basal ganglia and cortex. Ann Rev Neurosci 1986;9:357-381.

121 Zahm DS, Williams E, Wohltmann C: Ventral striatopallidothalamic projection: IV. Relative involvements of neurochemically distinct subterritories in the ventral pallidum and adjacent parts of the rostroventral forebrain. J Comp Neurol 1996;364:340-362.

122 Groenewegen HJ, Berendse HW, Haber SN: Organization of the output of the ventral striatopallidal system in the rat: ventral pallidal efferents. Neuroscience 1993;57:113-142.

123 O’Donnell P, Lavín A, Enquist LW, Grace AA, Card JP: Interconnected parallel circuits between rat nucleus accumbens and thalamus revealed by retrograde transynaptic transport of pseudorabies virus. J Neurosci 1997; 17:2143-2167.

124 Haber SN, Fudge JL, McFarland NR: Striatonigrostriatal pathways in primates form an ascending spiral from the shell to the dorsolateral striatum. J Neurosci 2000;20:23692382.

125 Alexander GE, Crutcher MD: Functional architecture of basal ganglia circuits: neural substrates of parallel processing. Trends Neurosci 1990;13:266-271.

126 Cummings JL: Frontal-subcortical circuits and human behavior. Arch Neurol 1993;50: 873-880.

127 Kelley AE, Baldo BA, Pratt WE, Will MJ: Corticostriatal-hypothalamic circuitry and food motivation: integration of energy, action and reward. Physiol Behav 2005;86:773-795.

128 Swanson LW: Cerebral hemisphere regulation of motivated behavior. Brain Res 2000; 886:113-164.

129 Belin D, Jonkman S, Dickinson A, Robbins TW, Everitt BJ: Parallel and interactive learning processes within the basal ganglia: relevance for the understanding of addiction. Behav Brain Res 2009;199:89-102.

130 Wise RA: Neuroleptics and operant behavior: the anhedonia hypothesis. Behav Brain Sci 1982;5:39.
131 Kelly PH, Seviour PW, Iversen SD: Amphetamine and apomorphine responses in the rat following 6-OHDA lesions of the nucleus accumbens septi and corpus striatum. Brain Res 1975;94:507-522.

132 Roberts MD, et al: Dopamine D1 receptor modulation in nucleus accumbens lowers voluntary wheel running in rats bred to run high distances. Physiol Behav 2012;105:661668.

133 Swanson C, Heath S, Stratford T, Kelley A: Differential behavioral responses to dopaminergic stimulation of nucleus accumbens subregions in the rat. Pharmacol Biochem Behav 1997;58:933-945.

134 Gong W, Neill DB, Lynn M, Justice JB Jr: Dopamine D1/D2 agonists injected into nucleus accumbens and ventral pallidum differentially affect locomotor activity depending on site. Neuroscience 1999;93:13491358.

135 Dreher JK, Jackson DM: Role of D1 and D2 dopamine receptors in mediating locomotor activity elicited from the nucleus accumbens of rats. Brain Res 1989;487:267-277.

136 Everitt BJ, Morris KA, O’Brien A, Robbins TW: The basolateral amygdala-ventral striatal system and conditioned place preference: further evidence of limbic-striatal interactions underlying reward-related processes. Neuroscience 1991;42:1-18.

137 Carr GD, White NM: Conditioned place preference from intra-accumbens but not intra-caudate amphetamine injections. Life Sci 1983;33:2551-2557.

138 Wadenberg M-L, Ericson E, Magnusson O, Ahlenius S: Suppression of conditioned avoidance behavior by the local application of (-)sulpiride into the ventral, but not the dorsal, striatum of the rat. Biol Psychiatry 1990;28:297-307.

139 McCullough LD, Sokolowski JD, Salamone JD: A neurochemical and behavioral investigation of the involvement of nucleus accumbens dopamine in instrumental avoidance. Neuroscience 1993;52:919-925.

140 Basar K, et al: Nucleus accumbens and impulsivity. Prog Neurobiol 2010;92:533-557.

141 Kuhnen CM, Knutson B: The neural basis of financial risk taking. Neuron 2005;47:763770.

142 Mogenson GJ, Wu M: Neuropharmacological and electrophysiological evidence implicating the mesolimbic dopamine system in feeding responses elicited by electrical stimulation of the medial forebrain bundle. Brain Res 1982;253:243-251.

143 Avena NM, Rada P, Moise N, Hoebel BG: Sucrose sham feeding on a binge schedule releases accumbens dopamine repeatedly and eliminates the acetylcholine satiety response. Neuroscience 2006;139:813-820.

144 Avena NM, Rada P, Hoebel BG: Underweight rats have enhanced dopamine release and blunted acetylcholine response in the nucleus accumbens while bingeing on sucrose. Neuroscience 2008;156:865-871. 
145 Mark GP, Rada P, Pothos E, Hoebel BG: Effects of feeding and drinking on acetylcholine release in the nucleus accumbens, striatum, and hippocampus of freely behaving rats. J Neurochem 1992;58:2269-2274.

146 Di Chiara G, Tanda G: Blunting of reactivity of dopamine transmission to palatable food: a biochemical marker of anhedonia in the CMS model? Psychopharmacology 1997; 134:351-353.

147 Bassareo V, Di Chiara G: Modulation of feeding-induced activation of mesolimbic dopamine transmission by appetitive stimuli and its relation to motivational state. Eur J Neurosci 1999;11:4389-4397.

148 Lawrence NS, Hinton EC, Parkinson JA, Lawrence AD: Nucleus accumbens response to food cues predicts subsequent snack consumption in women and increased body mass index in those with reduced self-control. Neuroimage 2012;63:415-422.

149 Everitt BJ: Sexual motivation: a neural and behavioural analysis of the mechanisms underlying appetitive and copulatory responses of male rats. Neurosci Biobehav Rev 1990; 14:217-232.

150 Platek SM, Singh D: Optimal waist-to-hip ratios in women activate neural reward centers in men. PLoS One 2010;5:e9042.

151 Rebec GV, Grabner CP, Johnson M, Pierce RC, Bardo MT: Transient increases in catecholaminergic activity in medial prefrontal cortex and nucleus accumbens shell during novelty. Neuroscience 1997;76: 707-714.

152 Mitchell JB, Gratton A: Involvement of mesolimbic dopamine neurons in sexual behaviors: implications for the neurobiology of motivation. Rev Neurosci 1994;5:317-329.

$\checkmark 153$ Robbins TW, Cador M, Taylor JR, Everitt BJ: Limbic-striatal interactions in reward-related processes. Neurosci Biobehav Rev 1989; 13:155-162.

154 Di Chiara G: The role of dopamine in drug abuse viewed from the perspective of its role in motivation. Drug Alcohol Depend 1995; 38:95-137.

-155 Berns GS, McClure SM, Pagnoni G, Montague PR: Predictability modulates human brain response to reward. J Neurosci 2001; 21:2793-2798.

156 Grubert C, et al: Neuropsychological safety of nucleus accumbens deep brain stimulation for major depression: effects of 12-month stimulation. World J Biol Psychiatry 2011;12:516-527.

157 Carelli RM: Nucleus accumbens cell firing during goal-directed behaviors for cocaine vs 'natural' reinforcement. Physiol Behav 2002;76:379-387.

-158 Goto Y, Grace AA: Dopaminergic modulation of limbic and cortical drive of nucleus accumbens in goal-directed behavior. Nature Neurosci 2005;8:805-812.

159 Yun IA, Wakabayashi KT, Fields HL, Nicola SM: The ventral tegmental area is required for the behavioral and nucleus accumbens neuronal firing responses to incentive cues. J Neurosci 2004;24:2923-2933.

160 Balleine B, Killcross S: Effects of ibotenic acid lesions of the nucleus accumbens on instrumental action. Behav Brain Res 1994;65: 181-193.

161 Cardinal RN, Parkinson JA, Hall J, Everitt BJ: Emotion and motivation: the role of the amygdala, ventral striatum, and prefrontal cortex. Neurosci Biobehav Rev 2002;26: 321-352.

162 Berridge KC, Robinson TE: What is the role of dopamine in reward: hedonic impact, reward learning, or incentive salience? Brain Res Rev 1998;28:309-369.

163 Yin HH, Ostlund SB, Balleine BW: Rewardguided learning beyond dopamine in the nucleus accumbens: the integrative functions of cortico-basal ganglia networks. Eur J Neurosci 2008;28:1437-1448.

164 Wager TD, Davidson ML, Hughes BL, Lindquist MA, Ochsner KN: Prefrontal-subcortical pathways mediating successful emotion regulation. Neuron 2008;59:1037-1050.

165 Salamone JD: The involvement of nucleus accumbens dopamine in appetitive and aversive motivation. Behav Brain Res 1994; 61:117-133.

166 Parkinson JA, Olmstead MC, Burns LH, Robbins TW, Everitt BJ: Dissociation in effects of lesions of the nucleus accumbens core and shell on appetitive Pavlovian approach behavior and the potentiation of conditioned reinforcement and locomotor activity by D-amphetamine. J Neurosci 1999; 19:2401-2411.

167 van der Plasse G, Schrama R, van Seters SP, Vanderschuren LJMJ, Westenberg HGM: Deep brain stimulation reveals a dissociation of consummatory and motivated behaviour in the medial and lateral nucleus accumbens shell of the rat. PLoS One 2012; 7:e33455.

168 Alderson HL, Parkinson JA, Robbins TW, Everitt BJ: The effects of excitotoxic lesions of the nucleus accumbens core or shell regions on intravenous heroin self-administration in rats. Psychopharmacology (Berl) 2001;153:455-463.

169 Bossert JM, Poles GC, Wihbey KA, Koya E, Shaham Y: Differential effects of blockade of dopamine D1-family receptors in nucleus accumbens core or shell on reinstatement of heroin seeking induced by contextual and discrete cues. J Neurosci 2007;27:1265512663.

170 Bossert JM, Gray SM, Lu L, Shaham Y: Activation of group II metabotropic glutamate receptors in the nucleus accumbens shell attenuates context-induced relapse to heroin seeking. Neuropsychopharmacology 2006; 31:2197-2209.

$\checkmark 171$ Maldonado-Irizarry CS, Kelley AE: Excitatory amino acid receptors within nucleus accumbens subregions differentially mediate spatial learning in the rat. Behav Pharmacol 1995;6:527-539.
172 Parkinson JA, Willoughby PJ, Robbins TW, Everitt BJ: Disconnection of the anterior cingulate cortex and nucleus accumbens core impairs Pavlovian approach behavior: further evidence for limbic cortical-ventral striatopallidal systems. Behav Neurosci 2000;114:42-63.

173 Ito R, Robbins TW, Everitt BJ: Differential control over cocaine-seeking behavior by nucleus accumbens core and shell. Nat Neurosci 2004;7:389-397.

174 Hernandez PJ, Sadeghian K, Kelley AE: Early consolidation of instrumental learning requires protein synthesis in the nucleus accumbens. Nat Neurosci 2002;5:1327-1331.

175 Corbit LH, Muir JL, Balleine BW: The role of the nucleus accumbens in instrumental conditioning: evidence of a functional dissociation between accumbens core and shell. J Neurosci 2001;21:3251-3260.

176 Cardinal RN, Cheung TH: Nucleus accumbens core lesions retard instrumental learning and performance with delayed reinforcement in the rat. BMC Neurosci 2005;6:9.

177 Basso AM, Kelley AE: Feeding induced by GABA(A) receptor stimulation within the nucleus accumbens shell: regional mapping and characterization of macronutrient and taste preference. Behav Neurosci 1999;113: 324-336.

178 Kelley AE, Swanson CJ: Feeding induced by blockade of AMPA and kainate receptors within the ventral striatum: a microinfusion mapping study. Behav Brain Res 1997;89: 107-113.

179 Pijnenburg AJJ, van Rossum JM: Stimulation of locomotor activity following injection of dopamine into the nucleus accumbens. J Pharm Pharmacol 1973;25:10031005.

180 Costall B, Naylor RJ: The behavioural effects of dopamine applied intracerebrally to areas of the mesolimbic system. Eur J Pharmacol 1975;32:87-92.

181 Freedman SB, Wait CP, Woodruff GN: Effects of dopamine receptor agonists and antagonists in the rat nucleus accumbens (proceedings). Br J Pharmacol 1979;67:430P$431 \mathrm{P}$.

182 Matsuda W, et al: Single nigrostriatal dopaminergic neurons form widely spread and highly dense axonal arborizations in the neostriatum. J Neurosci 2009;29:444-453.

183 Berlanga ML, et al: Cholinergic interneurons of the nucleus accumbens and dorsal striatum are activated by the self-administration of cocaine. Neuroscience 2003;120:11491156.

184 Zahm DS: Compartments in rat dorsal and ventral striatum revealed following injection of 6-hydroxydopamine into the ventral mesencephalon. Brain Res 1991;552:164-169.

185 Jones SR, O’Dell SJ, Marshall JF, Wightman RM: Functional and anatomical evidence for different dopamine dynamics in the core and shell of the nucleus accumbens in slices of rat brain. Synapse 1996;23:224-231. 
186 Kalivas PW, Duffy P: Selective activation of dopamine transmission in the shell of the nucleus accumbens by stress. Brain Res 1995;675:325-328.

187 King D, Zigmond MJ, Finlay JM: Effects of dopamine depletion in the medial prefrontal cortex on the stress-induced increase in extracellular dopamine in the nucleus accumbens core and shell. Neuroscience 1997;77: 141-153.

188 Chiara G, Tanda G, Frau R, Carboni E: On the preferential release of dopamine in the nucleus accumbens by amphetamine: further evidence obtained by vertically implanted concentric dialysis probes. Psychopharmacology 1993;112:398-402.

189 Pontieri FE, Tanda G, Di Chiara G: Intravenous cocaine, morphine, and amphetamine preferentially increase extracellular dopamine in the 'shell' as compared with the 'core' of the rat nucleus accumbens. Proc Natl Acad Sci U S A 1995;92:12304-12308.

190 Marcus MM, Nomikos GG, Svensson TH: Differential actions of typical and atypical antipsychotic drugs on dopamine release in the core and shell of the nucleus accumbens. Eur Neuropsychopharmacol 1996;6:29-38.

-191 Bardo MT, Hammer RP Jr: Autoradiographic localization of dopamine D1 and D2 receptors in rat nucleus accumbens: resistance to differential rearing conditions. Neuroscience 1991;45:281-290.

$\$ 192$ Jones DL, Mogenson GJ: Nucleus accumbens to globus pallidus GABA projection: electrophysiological and iontophoretic investigations. Brain Res 1980;188:93-105.

193 Givens B, Sarter M: Modulation of cognitive processes by transsynaptic activation of the basal forebrain. Behav Brain Res 1997;84: $1-22$.

194 Sarter M, Bruno JP: Cortical acetylcholine, reality distortion, schizophrenia, and Lewy body dementia: too much or too little cortical acetylcholine? Brain Cogn 1998;38:297-316.

195 Wachtel H, Anden N-E: Motor activity of rats following intracerebral injections of drugs influencing GABA mechanisms. Naunyn Schmiedebergs Arch Pharmacol 1978 302:133-139.

196 Jones DL, Mogenson GJ, Wu M: Injections of dopaminergic, cholinergic, serotoninergic and gabaergic drugs into the nucleus accumbens: effects on locomotor activity in the rat. Neuropharmacology 1981;20:29-37.

-197 Pycock C, Horton R: Evidence for an accumbens-pallidal pathway in the rat and its possible gabaminergic control. Brain Res 1976; 110:629-634.

198 Shreve PE, Uretsky NJ: Effect of GABAergic transmission in the subpallidal region on the hypermotility response to the administration of excitatory amino acids and picrotoxin into the nucleus accumbens. Neuropharmacology 1988;27:1271-1277.

199 Hamilton MH, De Belleroche JS, Gardiner IM, Herberg LJ: Stimulatory effect of Nmethyl aspartate on locomotor activity and transmitter release from rat nucleus accumbens. Pharmacol Biochem Behav 1986;25: 943-948.

200 Mogenson GJ, Nielsen M: A study of the contribution of hippocampal-accumbenssubpallidal projections to locomotor activity. Behav Neural Biol 1984;42:38-51.

201 Schacter GB, Yang CR, Innis NK, Mogenson GJ: The role of the hippocampal-nucleus accumbens pathway in radial-arm maze performance. Brain Res 1989;494:339-349.

202 Ericson E, Svensson TH, Ahlenius S: Loss of discriminative avoidance behavior by local application of kynurenic acid into the nucleus accumbens of the rat. Pharmacol Biochem Behav 1990;37:843-845.

203 Roberts PJ, Anderson SD: Stimulatory effect of L-glutamate and related amino acids on $\left[{ }^{3} \mathrm{H}\right]$ dopamine release from rat striatum: an in vitro model for glutamate actions. J Neurochem 1979;32:1539-1545.

204 Imperato A, Honoré T, Jensen LH: Dopamine release in the nucleus caudatus and in the nucleus accumbens is under glutamatergic control through non-NMDA receptors: a study in freely-moving rats. Brain Res 1990;530:223-228.

205 Boldry RC, Willins DL, Wallace LJ, Uretsky $\mathrm{NJ}$ : The role of endogenous dopamine in the hypermotility response to intra-accumbens AMPA. Brain Res 1991;559:100-108.

206 Pulvirenti L, Swerdlow NR, Koob GF: Microinjection of a glutamate antagonist into the nucleus accumbens reduces psychostimulant locomotion in rats. Neurosci Lett 1989; 103:213-218.

207 Donzanti BA, Uretsky NJ: Effects of excitatory amino acids on locomotor activity after bilateral microinjection into the rat nucleus accumbens: possible dependence on dopaminergic mechanisms. Neuropharmacology 1983;22:971-981.

208 Boldry RC, Layer RT, Wallace LJ, Uretsky NJ: Stimulation of locomotor activity by intra-accumbens AMPA is not inhibited by neonatal 6-hydroxydopamine-induced lesions. Neurosci Lett 1992;138:265-269.

209 Cornish JL, Kalivas PW: Glutamate transmission in the nucleus accumbens mediates relapse in cocaine addiction. J Neurosci 2000;20:RC89.

210 Kelley AE, Smith-Roe SL, Holahan MR: Response-reinforcement learning is dependent on N-methyl-D-aspartate receptor activation in the nucleus accumbens core. Proc Natl Acad Sci U S A 1997;94:12174-12179.

211 Grilli M, Summa M, Salamone A, et al: In vitro exposure to nicotine induces endocytosis of presynaptic AMPA receptors modulating dopamine release in rat nucleus accumbens nerve terminals. Neuropharmacology 2012;63:916-926.

212 Ciano PD, Everitt BJ: Dissociable effects of antagonism of NMDA and AMPA/KA receptors in the nucleus accumbens core and shell on cocaine-seeking behavior. Neuropsychopharmacology 2001;25:341-360.
213 Avena NM, Rada PV: Cholinergic modulation of food and drug satiety and withdrawal. Physiol Behav 2012;106:332-336.

214 See R, McLaughlin J, Fuchs R: Muscarinic receptor antagonism in the basolateral amygdala blocks acquisition of cocainestimulus association in a model of relapse to cocaine-seeking behavior in rats. Neuroscience 2003;117:477-483.

215 Yeomans J, Baptista M: Both nicotinic and muscarinic receptors in ventral tegmental area contribute to brain-stimulation reward. Pharmacol Biochem Behav 1997;57:915921.

216 Blaha CD, et al: Modulation of dopamine efflux in the nucleus accumbens after cholinergic stimulation of the ventral tegmental area in intact, pedunculopontine tegmental nucleus-lesioned, and laterodorsal tegmental nucleus-lesioned rats. J Neurosci 1996; 16 : 714-722.

217 Blaha CD, Winn P: Modulation of dopamine efflux in the striatum following cholinergic stimulation of the substantia nigra in intact and pedunculopontine tegmental nucleus-lesioned rats. J Neurosci 1993;13: 1035-1044.

218 Yeomans JS: Role of tegmental cholinergic neurons in dopaminergic activation, antimuscarinic psychosis and schizophrenia. Neuropsychopharmacology 1995;12:3-16.

219 Phelps PE, Vaughn JE: Immunocytochemical localization of choline acetyltransferase in rat ventral striatum: a light and electron microscopic study. J Neurocytol 1986; 15 : 595-617.

220 Suzuki T, Miura M, Nishimura K, Aosaki T: Dopamine-dependent synaptic plasticity in the striatal cholinergic interneurons. J Neurosci 2001;21:6492-6501.

221 Calabresi P, Centonze D, Gubellini P, Bernardi G: Activation of M1-like muscarinic receptors is required for the induction of corticostriatal LTP. Neuropharmacology 1999;38:323-326

222 Aosaki T, et al: Responses of tonically active neurons in the primate's striatum undergo systematic changes during behavioral sensorimotor conditioning. J Neurosci 1994;14: 3969-3984.

223 Witten IB, et al: Cholinergic interneurons control local circuit activity and cocaine conditioning. Science 2010;330:1677-1681.

224 Rada P, Avena NM, Hoebel BG: Daily bingeing on sugar repeatedly releases dopamine in the accumbens shell. Neuroscience 2005; 134:737-744.

225 Wise R, et al: Fluctuations in nucleus accumbens dopamine concentration during intravenous cocaine self-administration in rats. Psychopharmacology 1995;120:10-20.

226 Pothos E, Rada P, Mark GP, Hoebel BG: Dopamine microdialysis in the nucleus accumbens during acute and chronic morphine, naloxone-precipitated withdrawal and clonidine treatment. Brain Res 1991; 566:348-350. 
227 Carelli RM, Deadwyler SA: Dual factors con- 242 Neill D: Problems of concept and vocabulary trolling activity of nucleus accumbens cellfiring during cocaine self-administration. Synapse 1996;24:308-311.

228 Chang JY, Sawyer SF, Lee RS, Woodward DJ: Electrophysiological and pharmacological evidence for the role of the nucleus accumbens in cocaine self-administration in freely moving rats. J Neurosci 1994;14:1224-1244.

229 Peoples LL, Uzwiak AJ, Gee F, West MO: Operant behavior during sessions of intravenous cocaine infusion is necessary and sufficient for phasic firing of single nucleus accumbens neurons. Brain Res 1997;757: 280-284.

230 Hyman SE: Addiction to cocaine and amphetamine. Neuron 1996;16:901-904.

231 Pettit HO, Justice JB Jr: Dopamine in the nucleus accumbens during cocaine self-administration as studied by in vivo microdialysis. Pharmacol Biochem Behav 1989;34:899-904.

232 Koob GF, Maldonado R, Stinus L: Neural substrates of opiate withdrawal. Trends Neurosci 1992;15:186-191.

233 Chiara GD, Alan North R: Neurobiology of opiate abuse. Trends Pharmacol Sci 1992;13: 185-193.

-234 Shippenberg TS, Herz A, Spanagel R, BalsKubik R, Stein C: Conditioning of opioid reinforcement: neuroanatomical and neurochemical substrates. Ann NY Acad Sci 1992; 654:347-356.

-235 Diana M, Pistis M, Carboni S, Gessa GL, Rossetti ZL: Profound decrement of mesolimbic dopaminergic neuronal activity during ethanol withdrawal syndrome in rats: electrophysiological and biochemical evidence. Proc Natl Acad Sci U S A 1993;90: 7966-7969.

-236 Dani JA, Heinemann S: Molecular and cellular aspects of nicotine abuse. Neuron 1996; 16:905-908.

237 Corrigall W, Franklin K, Coen K, Clarke P: The mesolimbic dopaminergic system is implicated in the reinforcing effects of nicotine. Psychopharmacology 1992;107:285-289.

238 Tanda G, Pontieri FE, Di Chiara G: Cannabinoid and heroin activation of mesolimbic dopamine transmission by a common mul opioid receptor mechanism. Science 1997; 276:2048-2050.

-239 Carlezon WA Jr, Wise RA: Microinjections of phencyclidine (PCP) and related drugs into nucleus accumbens shell potentiate medial forebrain bundle brain stimulation reward. Psychopharmacology (Berl) 1996;128: 413-420.

240 Carlezon WA Jr, Wise RA: Rewarding actions of phencyclidine and related drugs in nucleus accumbens shell and frontal cortex. J Neurosci 1996; 16:3112-3122.

241 Parkinson JA, et al: Nucleus accumbens dopamine depletion impairs both acquisition and performance of appetitive Pavlovian approach behaviour: implications for mesoaccumbens dopamine function. Behav Brain Res 2002;137:149-163. in the anhedonia hypothesis. Behav Brain Sci 1982;5:70.

243 Melis M, Spiga S, Diana M: The dopamine hypothesis of drug addiction: hypodopaminergic state. Int Rev Neurobiol 2005;63:101154.

244 Wise RA: Action of drugs of abuse on brain reward systems. Pharmacol Biochem Behav 1980;13(suppl 1):213-223.

245 Di Chiara G: Drug addiction as dopaminedependent associative learning disorder. Eur J Pharmacol 1999;375:13-30.

246 Hyman SE, Malenka RC: Addiction and the brain: the neurobiology of compulsion and its persistence. Nat Rev Neurosci 2001;2: 695-703.

247 Salamone JD, Cousins MS, Snyder BJ: Behavioral functions of nucleus accumbens dopamine: empirical and conceptual problems with the anhedonia hypothesis. Neurosci Biobehav Rev 1997;21:341-359.

248 Kakade S, Dayan P: Dopamine: generalization and bonuses. Neural Netw 2002;15: 549-559.

249 Van den Oever MC, Spijker S, Smit AB: The synaptic pathology of drug addiction. Adv Exp Med Biol 2012;970:469-491.

250 Di Chiara G, Imperato A: Drugs abused by humans preferentially increase synaptic dopamine concentrations in the mesolimbic system of freely moving rats. Proc Natl Acad Sci U S A 1988;85:5274-5278.

251 Saal D, Dong Y, Bonci A, Malenka RC: Drugs of abuse and stress trigger a common synaptic adaptation in dopamine neurons. Neuron 2003;37:577-582.

252 Ungless MA, Whistler JL, Malenka RC, Bonci A: Single cocaine exposure in vivo induces long-term potentiation in dopamine neurons. Nature 2001;411:583-587.

253 Peoples LL, West MO: Phasic firing of single neurons in the rat nucleus accumbens correlated with the timing of intravenous cocaine self-administration. J Neurosci 1996; 16:3459-3473.

254 Li Q, Wang Y, Zhang Y, et al: Craving correlates with mesolimbic responses to heroinrelated cues in short-term abstinence from heroin: an event-related fMRI study. Brain Res 2012;1469:63-72.

255 Kilts CD: The neural correlates of cue-induced craving in cocaine-dependent women. Am J Psychiatry 2004;161:233-241.

256 Kilts CD, Schweitzer JB, Quinn CK, et al: Neural activity related to drug craving in cocaine addiction. Arch Gen Psychiatry 2001; 58:334-341.

257 De Ridder D, Vanneste S, Kovacs S, Sunaert S, Dom G: Transient alcohol craving suppression by rTMS of dorsal anterior cingulate: an fMRI and LORETA EEG study. Neurosci Lett 2011;496:5-10.

258 David SP, et al: Ventral striatum/nucleus accumbens activation to smoking-related pictorial cues in smokers and nonsmokers: a functional magnetic resonance im- aging study. Biol Psychiatry 2005;58:488494.

259 Ko C-H, et al: Brain activities associated with gaming urge of online gaming addiction. J Psychiatr Res 2009;43:739-747.

260 Engelmann JM, et al: Neural substrates of smoking cue reactivity: a meta-analysis of fMRI studies. Neuroimage 2012;60:252262.

261 Volkow ND, et al: Cocaine cues and dopamine in dorsal striatum: mechanism of craving in cocaine addiction. J Neurosci 2006;26: 6583-6588.

262 Grant S, et al: Activation of memory circuits during cue-elicited cocaine craving. Proc Natl Acad Sci U S A 1996;93:12040-12045.

263 Childress AR, et al: Limbic activation during cue-induced cocaine craving. Am J Psychiatry 1999;156:11-18.

264 Pettit HO, Ettenberg A, Bloom FE, Koob GF: Destruction of dopamine in the nucleus accumbens selectively attenuates cocaine but not heroin self-administration in rats. Psychopharmacology (Berl) 1984;84:167-173.

265 Rassnick S, Stinus L, Koob GF: The effects of 6-hydroxydopamine lesions of the nucleus accumbens and the mesolimbic dopamine system on oral self-administration of ethanol in the rat. Brain Res 1993;623:16-24.

266 Puglisi-Allegra S, Ventura R: Prefrontal/ accumbal catecholamine system processes high motivational salience. Front Behav Neurosci 2012;6:31.

267 Katsidoni V, Apazoglou K, Panagis G: Role of serotonin 5-HT2A and 5-HT2C receptors on brain stimulation reward and the rewardfacilitating effect of cocaine. Psychopharmacology (Berl) 2011;213:337-354.

268 Hoplight BJ, Vincow ES, Neumaier JF: Cocaine increases 5-HT1B mRNA in rat nucleus accumbens shell neurons. Neuropharmacology 2007;52:444-449.

269 Peng X-Q, et al: Gamma-vinyl GABA inhibits cocaine-triggered reinstatement of drugseeking behavior in rats by a non-dopaminergic mechanism. Drug Alcohol Depend 2008;97:216-225.

270 Pitchers KK, et al: Natural reward experience alters AMPA and NMDA receptor distribution and function in the nucleus accumbens. PLoS One 2012;7:e34700.

271 Fischer-Smith KD, Houston ACW, Rebec GV: Differential effects of cocaine access and withdrawal on glutamate type 1 transporter expression in rat nucleus accumbens core and shell. Neuroscience 2012;210:333-339.

272 Wolf ME: The role of excitatory amino acids in behavioral sensitization to psychomotor stimulants. Prog Neurobiol 1998;54:679-720.

273 Stuber GD, Hopf FW, Hahn J, et al: Voluntary ethanol intake enhances excitatory synaptic strength in the ventral tegmental area. Alcohol Clin Exp Res 2008;32:1714-1720.

274 Zweifel LS, Argilli E, Bonci A, Palmiter RD: Role of NMDA receptors in dopamine neurons for plasticity and addictive behaviors. Neuron 2008;59:486-496. 
275 Wolf ME, Sun X, Mangiavacchi S, Chao SZ: 288 Kourrich S, Klug JR, Mayford M, Thomas Psychomotor stimulants and neuronal plasticity. Neuropharmacology 2004;47(suppl 1): 61-79.

-276 Kelley AE, Andrzejewski ME, Baldwin AE, Hernandez PJ, Pratt WE: Glutamate-mediated plasticity in corticostriatal networks: role in adaptive motor learning. Ann NY Acad Sci 2003;1003:159-168.

277 Guitart X, Thompson MA, Mirante CK, Greenberg ME, Nestler EJ: Regulation of cyclic AMP response element-binding protein (CREB) phosphorylation by acute and chronic morphine in the rat locus coeruleus. J Neurochem 1992;58:11681171.

-278 Tenayuca JM, Nazarian A: Hydrocodone and morphine possess similar rewarding effects and reduce ERK and CREB phosphorylation in the nucleus accumbens. Synapse 2012;66:918-922.

279 Larson EB, et al: Overexpression of CREB in the nucleus accumbens shell increases cocaine reinforcement in self-administering rats. J Neurosci 2011;31:16447-16457.

280 Mattson BJ, et al: Cocaine-induced CREB phosphorylation in nucleus accumbens of cocaine-sensitized rats is enabled by enhanced activation of extracellular signal-related kinase, but not protein kinase A. J Neurochem 2005;95:1481-1494.

281 Vialou V, et al: Serum response factor and cAMP response element binding protein are both required for cocaine induction of $\Delta$ FosB. J Neurosci 2012;32:7577-7584.

$\checkmark 282$ Nye HE, Hope BT, Kelz MB, Iadarola M, Nestler EJ: Pharmacological studies of the regulation of chronic FOS-related antigen induction by cocaine in the striatum and nucleus accumbens. J Pharmacol Exp Ther 1995;275:1671-1680.

283 Hope BT, et al: Induction of a long-lasting AP-1 complex composed of altered Fos-like proteins in brain by chronic cocaine and other chronic treatments. Neuron 1994;13: 1235-1244.

284 Moratalla R, Elibol B, Vallejo M, Graybiel AM: Network-level changes in expression of inducible Fos-Jun proteins in the striatum during chronic cocaine treatment and withdrawal. Neuron 1996;17:147-156.

285 Muller DL, Unterwald EM: D1 dopamine receptors modulate $\triangle \mathrm{FosB}$ induction in rat striatum after intermittent morphine administration. J Pharmacol Exp Ther 2005; 314:148-154.

286 Lee K-W, et al: Cocaine-induced dendritic spine formation in D1 and D2 dopamine receptor-containing medium spiny neurons in nucleus accumbens. Proc Natl Acad Sci U S A 2006;103:3399-3404.

287 Muschamp JW, Nemeth CL, Robison AJ, Nestler EJ, Carlezon WA Jr: $\triangle$ FosB enhances the rewarding effects of cocaine while reducing the pro-depressive effects of the kappaopioid receptor agonist U50488. Biol Psychiatry 2012;71:44-50. MJ: AMPAR-independent effect of striatal aCaMKII promotes the sensitization of cocaine reward. J Neurosci 2012;32:65786586.

289 Wiltgen BJ, Law M, Ostlund S, Mayford M, Balleine BW: The influence of Pavlovian cues on instrumental performance is mediated by CaMKII activity in the striatum. Eur J Neurosci 2007;25:2491-2497.

290 Loweth JA, et al: Transient overexpression of alpha-Ca $2^{+} /$calmodulin-dependent protein kinase II in the nucleus accumbens shell enhances behavioral responding to amphetamine. J Neurosci 2010;30:939-949.

291 Loweth JA, Baker LK, Guptaa T, Guillory AM, Vezina P: Inhibition of CaMKII in the nucleus accumbens shell decreases enhanced amphetamine intake in sensitized rats. Neurosci Lett 2008;444:157-160.

292 Anderson SM, et al: CaMKII: a biochemical bridge linking accumbens dopamine and glutamate systems in cocaine seeking. $\mathrm{Na}$ ture Neurosci 2008;11:344-353.

293 Nestler EJ: Molecular mechanisms of drug addiction. Neuropharmacology 2004; 47(suppl 1):24-32.

294 Nestler EJ: Transcriptional mechanisms of addiction: role of $\Delta$ FosB. Phil Trans R Soc B 2008;363:3245-3255.

295 Heller AS, et al: Reduced capacity to sustain positive emotion in major depression reflects diminished maintenance of frontostriatal brain activation. Proc Natl Acad Sci U S A 2009;106:22445-22450.

296 Baumann B, et al: Reduced volume of limbic system-affiliated basal ganglia in mood disorders: preliminary data from a postmortem study. J Neuropsychiatry Clin Neurosci 1999;11:71-78.

297 Nestler EJ, Carlezon WA Jr: The mesolimbic dopamine reward circuit in depression. Biol Psychiatry 2006;59:1151-1159.

298 Carlezon WA, et al: Regulation of cocaine reward by CREB. Science 1998;282:2272-2275.

299 Pliakas AM, et al: Altered responsiveness to cocaine and increased immobility in the forced swim test associated with elevated cAMP response element-binding protein expression in nucleus accumbens. J Neurosci 2001;21:7397-7403.

300 Barrot M, et al: CREB activity in the nucleus accumbens shell controls gating of behavioral responses to emotional stimuli. Proc Natl Acad Sci U S A 2002;99:11435-11440.

301 Svenningsson P, et al: Alterations in 5-HT1B receptor function by $\mathrm{p} 11$ in depression-like states. Science 2006;311:77-80.

302 Alexander B, Warner-Schmidt J, Eriksson TM, et al: Reversal of depressed behaviors in mice by 11 gene therapy in the nucleus accumbens. Sci Transl Med 2010;2:54ra76.

303 Bewernick BH, et al: Nucleus accumbens deep brain stimulation decreases ratings of depression and anxiety in treatment-resistant depression. Biol Psychiatry 2010;67: 110-116.
304 Schlaepfer TE, et al: Deep brain stimulation to reward circuitry alleviates anhedonia in refractory major depression. Neuropsychopharmacology 2008;33:368-377.

305 Malone DA Jr, et al: Deep brain stimulation of the ventral capsule/ventral striatum for treatment-resistant depression. Biol Psychiatry 2009;65:267-275.

306 Abelson JL, et al: Deep brain stimulation for refractory obsessive-compulsive disorder. Biol Psychiatry 2005;57:510-516.

307 Aouizerate B, et al: Deep brain stimulation of the ventral caudate nucleus in the treatment of obsessive-compulsive disorder and major depression. Case report. J Neurosurg 2004;101:682-686.

308 He F, et al: Evaluation of short-term psychological functions in opiate addicts after ablating the nucleus accumbens via stereotactic surgery. Stereotact Funct Neurosurg 2008;86:320-329.

309 Gao G, et al: Clinical study for alleviating opiate drug psychological dependence by a method of ablating the nucleus accumbens with stereotactic surgery. Stereotact Funct Neurosurg 2003;81:96-104.

310 Huff W, et al: Unilateral deep brain stimulation of the nucleus accumbens in patients with treatment-resistant obsessive-compulsive disorder: outcomes after one year. Clin Neurol Neurosurg 2010;112:137-143.

311 Kuhn J, et al: Deep brain stimulation of the nucleus accumbens and the internal capsule in therapeutically refractory Tourette-syndrome. J Neurol 2007;254:963-965.

312 Kuhn J, et al: Remission of alcohol dependency following deep brain stimulation of the nucleus accumbens: valuable therapeutic implications? J Neurol Neurosurg Psychiatry 2007;78:1152-1153.

313 Mantione M, van de Brink W, Schuurman PR, Denys D: Smoking cessation and weight loss after chronic deep brain stimulation of the nucleus accumbens: therapeutic and research implications: case report. Neurosurgery 2010;66:E218; discussion E218.

314 Rauch SL, et al: A functional neuroimaging investigation of deep brain stimulation in patients with obsessive-compulsive disorder. J Neurosurg 2006;104:558-565.

315 Mavridis I, Anagnostopoulou S: The human nucleus accumbens as a target for deep brain stimulation: anatomic study of electrode's target point and stereotactic coordinates. Minim Invasive Neurosurg 2009;52:212-215.

316 Denys D, et al: Deep brain stimulation of the nucleus accumbens for treatment-refractory obsessive-compulsive disorder. Arch Gen Psychiatry 2010;67:1061-1068.

317 Voges J, Müller U, Bogerts B, Münte T, Heinze HJ: Deep brain stimulation surgery for alcohol addiction. World Neurosurg 2013;80:e21-e31.

318 Zhao H, et al: Associations between personality changes and nucleus accumbens ablation in opioid addicts. Acta Pharmacol Sin 2012;33:588-593. 
$319 \mathrm{Wu} \mathrm{H}-\mathrm{M}$, et al: Preliminary findings in ablating the nucleus accumbens using stereotactic surgery for alleviating psychological dependence on alcohol. Neurosci Lett 2010; 473:77-81.

320 Kumar R, et al: Double-blind evaluation of subthalamic nucleus deep brain stimulation in advanced Parkinson's disease. Neurology 1998;51:850-855.

321 Limousin P, et al: Effect of parkinsonian signs and symptoms of bilateral subthalamic nucleus stimulation. Lancet 1995;345:9195.

322 Tass PA, et al: Obsessive-compulsive disorder: development of demand-controlled deep brain stimulation with methods from stochastic phase resetting. Neuropsychopharmacology 2003;28(suppl 1):S27-S34.
323 Zabek M, Sobstyl M, Koziara H, Dzierzecki S: Deep brain stimulation of the right nucleus accumbens in a patient with Tourette syndrome. Case report. Neurol Neurochir Pol 2008;42:554-559.

324 Ackermans L, Temel Y, Visser-Vandewalle V: Deep brain stimulation in Tourette's syndrome. Neurotherapeutics 2008;5:339-344.

325 Neuner I, et al: From psychosurgery to neuromodulation: deep brain stimulation for intractable Tourette syndrome. World J Biol Psychiatry 2009;10:366-376.

326 Heinze H-J, et al: Counteracting incentive sensitization in severe alcohol dependence using deep brain stimulation of the nucleus accumbens: clinical and basic science aspects. Front Hum Neurosci 2009;3:22.

327 Kuhn J, et al: Successful deep brain stimulation of the nucleus accumbens in severe alcohol dependence is associated with changed performance monitoring. Addict Biol 2011; 16:620-623.

328 Müller UJ, et al: Successful treatment of chronic resistant alcoholism by deep brain stimulation of nucleus accumbens: first experience with three cases. Pharmacopsychiatry 2009;42:288-291.
329 Heldmann M, et al: Deep brain stimulation of nucleus accumbens region in alcoholism affects reward processing. PLoS One 2012; 7:e36572.

330 Zhou H, Xu J, Jiang J: Deep brain stimulation of nucleus accumbens on heroin-seeking behaviors: a case report. Biol Psychiatry 2011;69:e41-e42.

331 Mallory GW, et al: The nucleus accumbens as a potential target for central poststroke pain. Mayo Clin Proc 2012;87:1025-1031.

332 Machado A: Safety study of deep brain stimulation to manage thalamic pain syndrome (DBS). http://clinicaltrials.gov/ct2/show/ NCT01072656.

333 Knight EJ, et al: Nucleus accumbens deep brain stimulation results in insula and prefrontal activation: a large animal fMRI study. PLoS One 2013;8:e56640. 